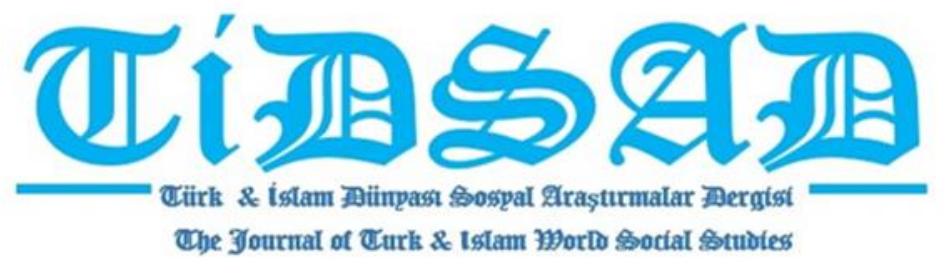

Yıl: 7, Sayı: 25, Haziran 2020, s. 98-135

Dr. Doğan YÜCEL

Tercüman, dyucel58@gmail.com

\title{
PEŞTUCADA TÜRKÇE/MOĞOLCA KELIMELER VE TÜRKÇE DİL UNSURLARI
}

\section{Özet}

Günümüz Afganistan toprakları verimli Hindistan ovalarıyla Orta Asya step ve çöllerini birbirinden ayıran bir ara tampon bölge gibidir. Tarihte kimi zaman Orta Asya/İrandan Hindistan'a geçenlerin ilk idari noktası olmuş kimi zaman da Hindistandaki topraklarını genişletmek isteyen devletlerin idaresine girmiştir. Orta Asyadan Hindistan'a geçen Türklerin de Afgan platoları -geçiş yolları üzerinde bulunması bakımından- ilk durak yerleri olmuştur. Türkçe ve Türkler için edebî, siyasî, kültürel ve sosyal tarih açısından belki Hindistan kadar önemli bir coğrafyadır. Bilinen tarih itibariyle 2500 yıla yakın bir etkileşim söz konusudur. Hindistan yarıkıtasının Kuzey, Batı ve Orta kısımları yüzlerce yıl çeşitli Türk devletlerinin idaresinde kalırken Afganistan da bu idarenin çoğu zaman bir parçası olmuştur. Kuşan devletiyle başlayıp 1725 yılında yerli Afgan şahının idaresine geçene kadar Afganistan'da aralıklarla neredeyse 1700-1800 yıl boyunca Türk idaresi vakidir. 45-60 milyon civarında konuşuru bulunan Peştuca, Türk Dili ve Türk tarihi açısından önemli lisanlardan biridir. Türklerin idaresi sırasında "üst dil" olan Türkçe mahallî Farsça ve Peştucayı ciddî şekilde tesiri altında bırakmıştır. Çalışmada kısaca Afganistan tarihi ve Türklerle ilişkili tarihi ele alınmıştır. Afgan dilinde yazılan hem ilk temel sözlükler hem de son dönemde yazılan sözlüklerden olmak üzere altı farklı Peştuca sözlük taranmıştır. Bu sözlüklerde geçen Türkçeden Afgan diline ödünçlenen kelime, ek ve yeniden üretilen hibrit kelimeler listelenmiştir. Çalışmamızda yeni üretimlerle birlikte 333 kelime ve dil unsuru tespit edilmiştir. Bilebildiğimiz kadarıyla Peştucadaki Türkçe kelimelere dair ilk ve tek çalışma dolaylı olarak Doerfer'in "Yeni Farsçadaki Türkçe ve Moğolca Kelimeler" adlı çalışmasıdır. Çalışmamız, Doerfer'in dolaylı çalışması bir tarafa bırakılırsa, ihmal edilen bu konuda ilk müstakil çalışmadır. Türkçe kelime ve unsurlara ilaveten 32 Moğolca kelime de listede yer bulmaktadır. Son olarak listenin sonuna Türkçeyle Batı dillerinden geçen örnek dört kelime eklenmiştir. 
Tespit edilen kelimeler tematik, morfolojik ve fonetik tasnife tabi tutulmuştur.

Anahtar Kelimeler: Peştuca, Afgan dili, Türkçe Ödünçlemeler, Dil ödünçlemeleri, Moğolca Ödünçlemeler.

\title{
TURKISH \& MONGOLIC WORDS AND TURKISH LEXICAL ELEMENTS IN PASHTO
}

\begin{abstract}
Today's Afghanistan is like an intermediate buffer zone separating fertile Indian plains and the steppes and deserts of Central Asia. In history, sometimes it was the first administrative point of those who crossed from Central Asia / Iran to India and at the same time it was under the rule of the states those wanted to expand their territory in India. Turks who had crossed from Central Asia to India were also the first stoppages in terms of the presence of Afghan plateaus on the transit routes. In terms of literary, political, cultural and social history, it is as important as lćke India for Turkish language and Turks. There is an interaction of about 2500 years as of known history. While North, West and Middle lands of India have remained under rule of various Turkish states for hundreds of years, Afghanistan has often been part of this Turkish administrations. Until 1725, the period of 1700-1800 Turkish administration was held in Afghanistan from beginning of the reign of the Kushan state and passed on to the administration of the local Afghan king in 1725. Pashto, which is spoken by about 45-60 millions, is one of the most important languages in terms of Turkish Language and Turkish history. The Turkish language, which was the "superstratum" during the administration of the Turks, has severely influenced Persian and Pashto languages in Afghanistan. Briefly, the history of Afghanistan and its history related to Turks are discussed in this paper. Six different Pashto dictionaries were scanned, both in the first basic dictionaries written in the Afghani language and dictionaries written recently. In these dictionaries, the words borrowed from Turkish into Afghan language, sufixes and reproduced hybrid words are listed. In our study, 333 words and language elements were identified. To the best of our knowledge, the first and only study of Turkish words in Pashto is indirectly Doerfer's "Turkish and Mongolian Words in New Persian". As far as we know that this work is the first work on this subject if the indirect work of Doerfer is left aside. In addition to Turkish words and elements, 32 Mongolian words are included in the list. Finally, four sample words from Western languages carried out through Turkish to Pashto were added to end of list. The determined words have been classified thematically, morphologically and phonetically.
\end{abstract}

Keywords: Pashto, Afghan Language, Turkish Loanwords, Lexical Borrowings, Mongolian Loanwords

\section{Giriş}

Günümüz Afganistan toprakları eski İran memleketiydi. Avestâ müellifleri bunu iyi bilmekteydi. Bilinen ilk devlet Keyaniyân devletidir. Herat, Helmand vadisi ve Sistan da bu 
memleketin hudutları dahilindeydi. Keyaniyân devletine dair malumat Herdot'un kayıtlarında bulunur. Bu devleti Makedonyalı İskender yıkmıştır. Bu döneme ait bazı bilgileri Firdevsî Şehnâmede işlemiştir (MEB-İA, IV-147-148). İskender'den sonra Celicius'un eline geçmiş devamında M.Ö. 231'e kadar Hind Mûriya devletinde kalmıştır. Kuşan Türk devletinin Afganistan topraklarını almasıyla Yunanlıların Afganistan istilası son bulmuştur. Kuşanların Afganistan hâkimiyeti M.Ö. 30- M.S. 50 yılları arasında başlamış ve Milâdî 5.asrın sonuna kadar devam etmiştir (MEB-İA, IV-149-150). Ak-hunlara yenilen Kuşanların Kâbil'deki varlıkları İslam ordularının 880'de Kâbil'i almasına kadar devam etmiştir. Afganistan'a ilk İslam fetih hareketleri Hz. Osman ve yoğun şekilde Hz. Muaviye zamanlarına rastlar. Sonraları Emevîler ve Abbasîler devirlerinde dört sefer daha yapılmıştır. 961 y1lında Sâmânoğullarında Hacib olan Alp Tigin Gazneliler devletini kurarak bölgeye tekrar Türk hâkimiyetini getirmiştir. Mahmud Gaznevî ile meşhur bu devletin mevcûdiyyeti Gurîlerin Gaznelileri 1187-88 yıllarında yıkmasına kadar sürmüştür. Gûrîlerden sonra bir diğer Türk hükümdar olan Yalduz Afganistan'a hakim olmuştur. Şemsuddin İltutmiş Yalduz'dan Afganistan'1 geri almışsa da sonrasında Moğollar bütün Afgan topraklarını istilâ etmişlerdir. İlhanlılar ve sonrasında Timur Afganistan'ı almıştır. Bâbür Şahın 1505'te Kâbil'i ülkesine katmasından itibaren 1725 yılında Bâbür devletinin Kâbildeki idaresi sona erene kadar Afganistan Türklerin idaresinde kalmıştır. Sonrasında yerli Afgan kıralları hüküm sürmüşlerdir. Bu kısa tarihçeden de anlaşıldığı üzere Afganistan coğrafyası son 300 yıl hariç 2000 y1l boyunca neredeyse kesintisiz şekilde irili ufaklı Türk devletleri arasında el değiştirip durmuştur.

\subsection{Kısaca Peştu Dili, Tarihi ve Edebiyatı}

Peştuca, kökeni bakımından 19.yy'da Hind-İran dillerinin Hind dilleri grubunda olarak düşünülmekteydi. Ancak Peştuca Hind dillerinden fonetik yapısıyla ayrılmaktadır (MEB-İA, IV-144). Buna ilaveten Toker, Peştucanın akraba dilleri olan Beluçça ve Farsçadan müennesmüzekkerli yapısı bakımından ayrıldığını bu yüzden de Şarkî Ârî dillerinden olduğunu söylemenin zorluğunu belirtir (2007, s. 255). "Peştu dili veya eski adlyla Afganca ödünçleme ve alıntıların çok bol olduğu bir dildir. Hatta Hind dillerinin bir kolu olduğu sanılacak kadar Hindceden kelime, masdar yapımı ve unsur bakımından müteessir olmuştur. Yeni Farsçadan da birçok kelimeler alınmıştır" (MEB-İA, IV-144). Arapça unsurlar genel itibariyle İslamdan sonra Peştu diline girmiştir. Peştu diliyle ilgili Batıda özellikle İngiliz ve Alman müelliflerce 19yy.'da önemli çalışmalar yapılmış ve bu dilin kelime hazinesi, gramer yapısı, akrabalıkları, deyimleri, önemli eserleri Batı ilim dünyasına kazandırılmıştır. İlk Afganca veya Peştuca gramer kitabı 1839 ' da hazırlanmıştır. Halk şiirleri ve folkloru derlenmiştir. Eserlerin kaynakçası için (MEB İA, 1985, IV-166-167) bakılabilir. Türkiye'de ise "Peştuca" maddeleri ve iki Afganlı tarihî şahsiyetin tanıtımı (DİB-İA: 2007, 34/254-255; MEB-İA, IV/144-145; ML, 16/25 vb), bir Türkçe-Peştuca sözlük, Peştu Dili Ve Edebiyatı ile ilgili Qoraboyev'in Peşaver'de kıssahanlığ anlattığ bir alt başlık olarak kısaca ele alınması (Yücel, 2013) dışında Türkçe çalışma bulamadık. Türkiye'de Peştu Dili ve Edebiyatı ile ilgili bir bölüm bulunmamaktadır.

"Peştuca iki ana gruba ayrılmaktadır: Yûsufzaî denilen kuzey lehçesi Peşaver ve Hatak Kandehârî denilen güney lehçesi. Bunlardan j ve ş'yi bilinen ses değerleriyle ifade eden 
lehçeye Hatak, $g, c, z$ ve kh ile ifade eden lehçeye ise Yûsufzaî denilmektedir. Bu fark dilin adlandırlmasında da belirleyici olmakta ve dile Hatak lehçesini konuşanlar "Peştû", Yûsufzầ lehçesini konuşanlar "Pehtû" adını vermektedir" (Toker, 2007, s. 255).

$\mathrm{Bu}$ iki lehçenin şive ve ağızlarının sayısı 20 kadardır (en.wikipedia.org). Peştucayı üç ana lehçeye ayıranlar da vardır: Pakistan'da konuşulan Kuzey Peştuca; Afganistan'da konuşulan Güney Peştuca; ve çoğunlukla yine Pakistan'da konuşulan Merkez Peştuca (www.omniglot.com). Peştuca konuşan insanlara Kuzey Afganistan'da "Pah̆tun", Güney Afganistan'da "Peştun" ve Pakistandakilere Pathan veya Afgan denilir.

Peştu Edebiyatı esas itibariyle XVI. milâdî asırda başlamıştır. Önceleri şifahî bir geleneğe sahiptir. 17yy. da Peştular'ın millî şairi ve kumandanı Hûşhâl Han Hatak'ın 16.000 beyitten ibaret Dîvân'ı Peştuca ve Farsça şiirlerini içerir, Fażlnâme ve Bâznâme ise Peştuca'dır (Toker, 2007, s. 255). Ahmad Şah Baba (1723-1773) zamanından itibaren Peştuca hukuk dili olmuştur. Ahmed Şah devrinde Pir Muhammad Kakar tarafindan Marifat el-Afgani (Afganca Malumatı) adıyla yazılmıştır. Ondan sonra Peştuca fiillerin olduğu ilk gramer kitabı Hindistan topraklarında Hafez Rahmatullah Khan'ın oğlu Barreitsh'in meşhur lideri Nawab Mohabat Khan'ın önderliğinde Riaz ul-Muhabbet (Sevgi Bahçesi) adıyla 1805'te yazılmıştır. Hafez Rahmat Khan'ın bir diğer oğlu Nawabullah Yar Khan Acayib-ul-Lugat (Lugat Harikaları) adıyla 1808 'de Peştuca bir sözlük yazmıştır (en.wikipedia.org). 1806'da neşredilen Riaz-ul Muhabbat'den 2002 senesine kadar kaleme alınan Peştuca lugatlerden 58 adedi Zazai tarafından bir liste hâline getirilmiştir. Bu listede İngilizce, Arapça, Fransızca, Rusça, Farsça, Japonca gibi dillerle Peştuca iki veya daha fazla dilli sözlükler bulunmaktadır. Ancak herhangi bir PeştucaTürkçe sözlük listede yoktur (zazai.ca).

Afganistan'da Dari ile birlikte ülkenin resmî dilidir. Pakistan'da Hayber-Pahtunva eyaletinin eyalet dilidir. 1896 yılında Sir Mortimer Durand tarafindan İngiliz Hindinin Garb sınırı 2.430 km olarak çizildi. Ancak bu hat Beluçların ve Peştuların Afganistan, İran ve Pakistan arasında bölünmesine sebep oldu.

"Afganistan Krallı̆̆ının 20. Yüzyıın ilk yarısında Peştuca ile ilgili yaptı̆̆ çalışmalar Peştucayı ülkenin ilk dili haline getirmiştir. 1930'lara kadar Farsça tek resmi dildi. Farsça günümüzde halen Afganistan'in Lingua Frankası olmaya devam etmektedir. 1930'larda ise Peştu Encumen Peştuca Cemiyeti adlı cemiyetin kurulması, Kabil Üniversitesinin 1932'de açılması ve 1937'de Peştu Tolana Peştuca Akademisi'nın yeniden şekillendirilmesinin ardindan sosyal bir hareket Peştucayı hükümet, idare ve sanat dili olma yolunda itmeye başladı. 1964 'te Anayasa Meclisi tarafindan resmi dillerin hüviyeti tekrar teyit edildi ve Afgan Farsçası "Dari”" şeklinde yeniden isimlendirildi. Afganistan'ın miili marşının güfteleri Peştucadır" (wikipedia.com).

Ancak Farsça ülkede yine eğitim ve havassın konuşmayı tercih ettiği, yazdığı ve okuduğu dil olmaya devam etmektedir. Ayrıca ülkede bulunan Özbek ve diğer Türk unsurlar da ikinci dil olarak Farsça konuşmaktadırlar.

"Peştu dilinde İran dil grubu ile Hint-Ârî ve Dravid dillerinde bulunmayan bazı 
sesler yer almaktadır. Bu dil için ilk olarak çivi yazısı, ardından Fenike yazısından türetilen bir alfabe kullanılmıştır. Bugünkü Arap alfabesi kaynaklı alfabede kırk bir harf bulunmaktadır. Bunlardan Peştuca'ya ait dört ses dişında kalanlar diğer bölge dilleriyle ortaktır. Peştuca'da Farsça ve Beluçça gibi İran dillerinde bulunmayan, ancak Urduca, Hindustânî ve Pencâbî gibi Hint dillerinde yer alan çeşitli özellikler ihtiva etmektedir. Söz konusu dillerle olan benzerliklerin yanı sıra Peştuca'da tamamen kendine has bazı özellikler de vardır" (Toker, 2007, s. 255).

Afganistan halkının üçte birini meydana getiren 4 milyon nüfuslu Afgan kabilelerinin ana dilidir (ML, 1992, 16/25). Peştuca konuşanların sayısı kesin olarak bilinmemekle birlikte, çoğu tahmin 45 milyon ile 55 milyon arasında değişmektedir. Peştuca, Afganistan halkının \% 40 ila \% 55'i (11 ila 15.4 milyon) birinci dil,\% 10 ila \% 28'i ise (2.8 ila 7.8 milyon kişi) ikinci dil olarak konuşmaktadır. Toplamda 19 milyon. Peştucanın Pakistan'da (nüfusun\% 15'i) Federal İdareli Kabile Bölgelerinde (FATA) ve Belucistan, Mianwali, Attock, Sindh, Pencap ve Hayber Pakhtunkhwa eyaletlerinde olmak üzere yaklaşık 25 milyon konuşuru vardır. Toplamda 45 milyon civarındadır (www.omniglot.com). Aynı coğrafyalarda olmak üzere yaklaşık 45-60 milyon insan tarafından konuşulduğuna dair kaynaklar da bulunmaktadır (en.wikipedia.org).

\subsection{Peştucadaki Türkçe Kelimeler}

Peştucaya geçen Türkçe/Moğolca kelime ve unsurlarla ilgili dolaylı olarak tek çalışma tespit edebildiğimiz kadarıyla Doerfer'indir. Doerfer'in sözlüğünde Farsçadaki Türkçe kelimelerden Afgan diline geçenler de belirtilmiştir (1963, 1965, 1967, 1975). Ancak Karaağaç, Doerfer'in Türkçe olduğu açık olan bazı kelimelerde tereddütlü davrandığını bazı kelimeleri Türkçe olmasına rağmen başka dillere ait olarak yazdığını ve Fars dilindeki birçok Türkçe kelimenin de eserinde yer bulmadığını söylemektedir (2004, s. 19). İslam ansiklopedisi "Bir çok Arap ve hatta bazı Türkçe kelimeler de Farsça vasıtasıyla Paştoya girmiştir"'demektedir. (MEB-İA, IV144). Hind dilleri üzerine ilk kapsamlı çalışma olan Grierson'un Linguistic Survey of India (Hindistan'ın Dil Araştırması) çalışmasında da Peştuca yer almamaktadır (1927, vol.1 part. 1, Tanıtım sayfası). Hem Hindistan'da hem de Afganistan'da tarihte kurulan Türk devletlerinin İslam sonrası resmî devlet dilleri uzun süre Farsça olduğundan bu iddianın bir doğruluk payı vardır. Ancak Farsçadaki Türkçe unsurların geniş çaplı bir çalışmasıyla alttaki listemizin mukayese edilmesi sonrası Türkçe unsurların Peştu diline geçişine Farsçanın ne kadar tavassut ettiği aşağı yukarı ortaya konabilecektir. Doerfer'in çalışmasındaki kelimelerle alttaki liste kıyaslandığında ise yaklaşık yarı yarıya kelimelerin ortak olduğu görülmektedir. 2013 yılında Yücel, "Pakistan'daki Urduca Ve Dört Ana Mahalli Dilin Tarihleri, Kullanım Sahaları Ile Cümle Yapıları Ve Fiil Çekimlerinin Türkçeyle Mukayesesi Ve Türkçe Kelimelerinin Taranması" adlı yüksek lisans tezinde bir alt başlık olarak Peştucadaki Türkçe kelimelere dair bir liste vermiştir. Bu listede 71 kelime bulunmakta olup etimolojilerine değinilmemiş olup sadece tematik gruplandırmaya gitmiştir (s. 100-120). Bahsi geçen bu iki çalışmanın haricinde taramalarımız neticesinde başka bir çalışma tespit edemedik.

\section{4. Çalıșmanın Amacı, Kapsamı ve Yöntemi}

Çalışmanın amacı; Peştu diline geçmiş olan Türkçe veya Moğolca kelimeleri Peştuca sözlüklerden bir liste hâlinde tespit edip fonetik, tematik ve morfolojik olarak tasnif etmektir. Ayrıca -varsa- Türkçe eklerle üretilen Peştuca kelimelerle Türkçe ve Moğolca kelimelere 
Peştuca ek/unsurlarla üretilen kelimelerin varlığını ve miktarını tablolarla ortaya koymaktır. Çalışmada antronimiler, toponimiler, deyimler, atasözleri yer almamaktadır. Kelimelerin detaylı tahlilleri yapılmamıştır. Kelime ve dil unsurları haricinde kalan dil kalıntıları, tercüme ifadeler, doğrudan tercümeler, Türkçeyle taşınan aslen Türkçe veya Moğolca olmayan kelime ve unsurlar da kapsam dışı bırakılmıştır. Bu noktada sadece birkaç örnek verilmekle iktifa edilmiştir.

Listedeki kelimelerin derlenmesinde Peştuca sözlüklerdeki kelimeler esas alınmıştır. Peştu dilinin iki eski sözlüğü, iki öğrenci sözlüğü, Peştu Akademisinin hazırladığı "Peştuca Sözlük”ün latin harfli versiyonu ve son dönemde yazılan en kapsamlı Peştuca sözlüklerden biri olan 860 sayfalık Pashtoon'un hazırladığı sözlük taranmıştır. Sözlüklerin üçü internette açık kaynaklardan diğerleri ABD ve Pakistan'dan temin edilmiştir.

Peştuca sözlüklerde Türkçe olarak verilen ancak Türkçe etimoloji sözlüklerinde Türkçe kökenli olarak gösterilmeyen kelimeler listeye dahil edilmemiştir. Taranan sözlüklerde Türkçe kökenine dair farklı etimolojik değerlendirmeler bulunan kelimelere yine Türkçe etimoloji sözlükleri esas alınarak çalışmada yer verilmiştir. Etimolojiler için; Eren'in “Türk Dilinin Etimolojik Sözlügüu”, Tietze'nin Tarihi ve Etimolojijk Türkiye Türkçesi Sözlüğü I-VI, Nişanyan'ın “Sözlerin Soyağac1, Clauson'ın "Etymological Dictionary of Pre-Thirteenth Century", Doerfer'in "Türkische und Mongolische Elemente im Neupersischen I-IV" adlı eserlerinden istifade edilmiştir. Tespit edilen kelimelerin Türkçe mukabilleri DLT'den başlayarak -14 farklı olmak üzere- 46 cilt sözlük taranarak bulunmaya çalış1lmıştır.

Listedeki ilk sütun Peştuca aslî imlâları gösterirken ikinci sütun Türkçe okunuşları göstermektedir. Üçüncü sütunda Peştuca kaynaklar, dördüncü sütunda Türkçe mukabili kaynaklar, beşinci sütunda morfolojik, altıncı sütunda tematik ve yedinci sütunda fonetik değerlendirmeler gösterilmektedir. Liste, Peştu dili alfabetik sırasına göre hazırlanmıştır.

\begin{tabular}{|c|c|c|c|}
\hline $\begin{array}{l}\text { Kisaltmalar } \\
\text { Redhouse An English and Turkish } \\
\text { Dictionary }\end{array}$ & ETDR & Gerhard Doerfer & GD \\
\hline Çağatai ve Turkî-i Osmanî & LÇ & Andreas Tietze & $\mathrm{AT}$ \\
\hline Derleme Sözlüğü & DS & Hasan Eren & $\mathrm{HE}$ \\
\hline Dictionarie Turk Oriental & DTO & TDV İslam Ansiklopedisi & TDVİA \\
\hline $\begin{array}{l}\text { Dict. of the Pukkhto or Pukshto Lang. } \\
\text { Bellew }\end{array}$ & DPPL & Sir Gerard Clauson & CEAT \\
\hline Divan-i Lugatit Türk & DLT & $\begin{array}{l}\text { Okyanus Ansiklopedik } \\
\text { Sözlük }\end{array}$ & OAS \\
\hline İbn-ü Mühenna Lugati & İML & Ötüken Türkçe Sözlük & ÖTS \\
\hline Kamus-i Turki & KT & Sevan Nişanyan & SN \\
\hline Lehçe-i Osmani & LO & Urduca & $\mathrm{U}$ \\
\hline Lugat-i Naci & $\mathrm{LN}$ & Arapça & A \\
\hline Mod Words English-Pashtu Dictionary & MWEP & Sindice & S \\
\hline Pakhto-Inglisi Qamoos & PIQ & Peştuca & PŞ \\
\hline Türkçe Sözlük TDK & TS & Farsça & $\mathrm{F}$ \\
\hline Urdu-Türkçe Sözlük & UTS & İtalyanca & İt \\
\hline Uzbek Tilining Izaxli Lugati & OTİL & Hintçe & $\mathrm{H}$ \\
\hline Pashto -English Dictionary & PED & Fransizca & $\mathrm{Fr}$ \\
\hline
\end{tabular}




$\begin{array}{llll}\text { English-Pashto Pashto-English Dictionary } & \text { EPPED } & \text { Moğolca } & \mathrm{Mg} \\ \text { Pashto-English Dictionary Arif Wardak } & \text { PEDA } & \text { Yunanca } & \mathrm{Y}\end{array}$

\section{Bulgu ve Yorumlar}

\subsection{Kelime Listesi}

Pş Aslı TR İmlâsı

Peştuca Kaynaklar

Türkçe Mukabiller

M T F

Türkçe Kelimeler

ئي̂اق Îlạ

Yaylak PED, 853

(يايلاق) Yaylak, yaz geçirililen

$1 \quad 12 \quad 1$

yüksek yer ETDR, 1132; (يايلاق

yayla DTO, 542; yaylak.. OTİL-

2, 476; IML, 88; yayla mahali..

LÇ, 302; (يايلاق zayın çıkılıp

ikamet olunan yüksek ve serin

yer.. KT, 1540; TaS-6, 4445;

LO-2, 1236; TS, 2152;

(yaylâg) DLT, 678; CEAT, 981;

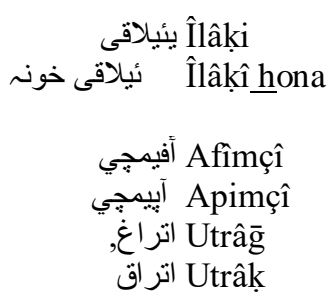

اجاع Ucâ'

اجٌار Açâr

İdâreçî

İtibațçî
Yaylağa dair. PED, 71

Yaylak ev, yazlık ev. PED, 71

Afyonkeş PED, 4-41;

Afyonkeş DPPLA, 40

Durma, eğlenme, dinlenme..

PED, 4; PED, 59

Ocak PED, 7

Turşu PED, 9; PEDA, 11

1.İdareci, müdür. 2.lider, rehber PED, 15

Askerî haberci, ulak PED, 18 İ̈revli. OAS-4, 1165

$\begin{array}{lll}3 & 12 & 1\end{array}$

$\begin{array}{lll}3 & 12 & 1\end{array}$

Afyonkeş, afyoncu. OAS-1, $25 \quad 2 \quad 8 \quad 1$

1. Oturulacak yer veya şey. $2 . \quad \begin{array}{llll}1 & 14 & 1\end{array}$

Tahtadan alçak iskemle. TS,

1520; DTO, 41; اوتوراق اوتر KT,

187; LO-1, 178; اوتراق LÇ, 24;

AT-6, 178; GD-2, 8

Ateş yakma yeri, baca

ETDR, 500; اوجاق Ocak, ateş

$1 \quad 12 \quad 2$

yakma yeri.. LO-1, 167; evde

yemek pişirme yeri.. DTO, 47;

اوجاق Ocak.. LÇ, 26 اوجاغ

yakılan yer.. KT, 190; UTS, 26;

Ateş yakmaya yarayan, pişirme, 1sıtma, ısınma gibi amaçlarla

kullanılan yer. TS, 1488; (oçaq)

DLT, 351; AT-6, 105; GD-2, 10

LÇ, 6 İştiha açmaya

mahsus turşu vesaire KT, 22;

bir çeşit sirke turşusu UTS, 16 ,

$\mathrm{F}$; iştah açmak için yemekten

önce içilen alkollü içki, aperitif.

TS, 10; turşu, aperitif AT-1, 21;

GD-2, 14

İdare eden, yöneten kimse; $\quad 2 \quad 2 \quad 2$

ülkenin yönetimiyle ilgili

Askerî haberci, ulak PED, 18 İrtibat subayı. OAS-4, 1237 


\begin{tabular}{|c|c|c|c|c|}
\hline Urdu & $\begin{array}{l}\text { Ordu PED, } 19 ; \text { Orduca } \\
\text { PEDA, 15; ordu, ordugâh } \\
\text { EPPED, } 182\end{array}$ & 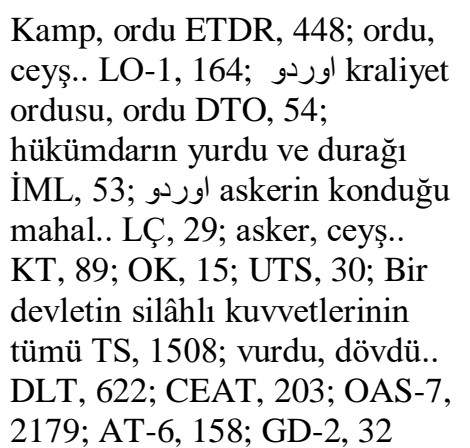 & 1 & 4 \\
\hline اردو كاه Urdugâh & Ordugah PED, 19 & $\begin{array}{l}\text { Askerî birliklerin dinlenmesi } \\
\text { için genellikle düşman teması } \\
\text { dışında bulunan bölgeler-de } \\
\text { önceden seçilmiş yerlere verilen } \\
\text { ad. OAS- } 7,2181\end{array}$ & 3 & 4 \\
\hline ق قول اردو Kul ordu & $\begin{array}{l}\text { Askeri birlik PED, 554; } \\
\text { askeri birlik PEDA, } 454\end{array}$ & Ordu kanadı. GD-1, 438 & 1 & 4 \\
\hline Armağan & $\begin{array}{l}\text { Armağan, yadigâr PED, 20; } \\
\text { hediye, müjde PEDA, } 16\end{array}$ & $\begin{array}{l}\text { Armağan, hediye, ödül TS-1, } \\
\text { 145; ETDR, 450; LN, 20, F; } \\
\text { LÇ, 10; آرغاKKT, 30; R-1, 339; } \\
\text { UTS, 30, F; Başarılı bir seferden } \\
\text { dönen bîrisinin yakınlarına } \\
\text { verdiği hediye, ödül DLT, 149; } \\
\text { AT-1; 123, ?; HE, 18; CEAT, } \\
\text { 232; GD-2, } 45\end{array}$ & 1 & 14 \\
\hline اوماتج Omâç & $\begin{array}{l}\text { Un çorbasi PEDA, 457; اماج } \\
\text { yeşillikli yumurta omleti. } \\
\text { PED, } 48\end{array}$ & $\begin{array}{l}\text { 1. Elle ufalanmış hamurdan } \\
\text { yapılan çorba. } 2 . .3 \text {. } \\
\text { Kavrulmamış buğday unundan } \\
\text { yapılan pelte koyuluğunda bir } \\
\text { yemek. 4. Parçalanmış yufka } \\
\text { ekmeğini yağda kızartarak } \\
\text { yapılan, istenirse üstüne yoğurt } \\
\text { dökülen çoban yemeği. } 5 \text {. } \\
\text { Ekmek, yağ ve pekmezz } \\
\text { karıştırılarak yapılan yemek. } 6 \text {. } \\
\text { Unu suyla karıștırarak yapıllan } \\
\text { hayvan yemi..7.. DS-9, 3268; } \\
\text { helva, un çorbası.. AT-6, 148; } \\
\text { GD-2, } 123\end{array}$ & 1 & 3 \\
\hline Uzbek & Özbek PED, 24 & $\begin{array}{l}\text { özbek halk1.. OTIL-2, 495; } \\
\text { olülmüstakil emir demek } \\
\text { olub.. KT, 202; TS, } 1554\end{array}$ & 1 & 7 \\
\hline As & Ermin PED, 25 & $\begin{array}{l}\text { Yırtıcı bir hayvan İML, 11; } \\
\text { kakum.. LÇ, 12; KT, 33; LO-1, } \\
\text { 31; ümit, güven UTS,18, H; TS, } \\
\text { 127; HE, } 20\end{array}$ & 1 & 11 \\
\hline أستثمارجي & $\begin{array}{l}\text { Menfaatçi, sömürücü PED, } \\
26 \text {; } \\
\text { PEDA, } 19\end{array}$ & $\begin{array}{l}\text { 1. Değerlendiren, değer biçen. } \\
\text { 2.Gümrüğe gelen eşyaya k1ymet } \\
\text { takdir eden kimse. } 3 \text {. } \\
\text { Muhammin OAS-4, } 1253\end{array}$ & 2 & 9 \\
\hline İstihḳâmçî استحكامِي & $\begin{array}{l}\text { İstihkamcı PED, 27; PEDA, } \\
19\end{array}$ & $\begin{array}{l}\text { İstihkâm sinıfindan kita, subay } \\
\text { ve erler. OAS- } 4,1250\end{array}$ & 2 & 4 \\
\hline استعمارجي İsti'mârçî & $\begin{array}{l}\text { Sömürgeci PED, 29; PEDA, } \\
20\end{array}$ & & 2 & 8 \\
\hline
\end{tabular}


Eşişte, turta PEDA, 5

$\begin{array}{ll}\text { İşâreçî̀ } & \text { İşaretçi PED, } 32 \\ \text { Utaḳ. } & \text { Otak, oda PED, } 35\end{array}$

اعتبارليى Ítibârlik

I Aka

Ak

गٓ Âl

$$
\begin{aligned}
& \text { Alarğa } \\
& \text { Alaça }
\end{aligned}
$$

İcazetname, teminat mektubu, diplomatik itibar.. PED, 36; kimlik, hüviyet PEDA, 25

Amca DPPL, 5; 1.Amca. 2.Yaşı büyük, yetişkin kims PED, 42; Amca PEDA, 28; amca EPPED, 184

1. Ak. 2. Bazı coğrafya terimlerinde kullanılır "aktepe" gibi PED, 41

K1z11, kırmızı PED, 44

Ala karga, alaca karga?, şahin. PED, 44 Alaca. PED, 45
Pişirilerek hazırlanan yemek TS-1, 149; yemek ETDR, 461; LN, 8, F; aş, yemek.. LO-1, 31; OTİL-1, 264, 554; yenecek şey IML, 12; LÇ, 13; KT, 33; TaS1, 254, F; اش DTO, 22; OK, 10; UTS,18, F; TS, 135; DLT, 155; HE, 23, ?; GD-2, 59

İşaretleyici, 1.işaret koymaya yarayan veya işaret koyan. 2 .. OAS-4, 1262

Büyük çadır ETDR, 499; اوتاق 112 oturacak yer, oda, çadır.. LO-1, 7; tente, oturulan yer.. DTO, 4; IML, 54; اوتاق oturulan veya ateş yakılan yer.. KT, 185; çadır.. TaS-5, 3022; otağ Büyük ve süslü çadır. TS, 1518; اوتاق LÇ, 24; UTS, 25; otâg DLT, 364; CEAT, 46; çadır DS-9, 3292; AT-6, 172; GD-2, 66

Teminat mektubu.. OAS-4, 12742

.. Büyük kardeş, ağabey TS-1, $1 \quad 1 \quad 2$ 51; ağa, sultan yaveri DTO, 27, 28; abi.. OTİL-1, 35; büyük birader.. LÇ, 17; İran Türkleri beyninde "ağa" yerine isti'mal olub, ancak orada ulemaya dahi 1tlak olunur KT, 43; TaS 1, 25; R-1, 96; ETDR, 475; hekim, sahip, koca,eş UTS, 19; TS, 46; büyük erkek kardeş DS-

12,4406; süt kardeş. GD-2, 154 Ak OTİL-1, 557; Ak, beyaz.. ETDR, 475; IMLL, 8; (آق LO-1, 44; (آغ Ak LÇ, 14; (آق KT, 43; R-1, 88; TS, 46; DLT, 146; AT1, 49; GD-2, 84

Kanın rengi, kızıl, kırmızı.. TS- $114 \quad 2$ 1, 69; kızıl, kırmızı ETDR, 481;

LN, 11, F; parlak kızıl LO-1, 52; OTİL-1, 528; kül renkli at. İML, 9; koyu penbe rengi.. LÇ, 17; koyu ve parlak penbe KT, 47; UTS, 19; TS, 62; ..olan turuncu renkte, ipekli süslü bir kumaş. Turuncu renge de âl denir. DLT, 137; CEAT, 120; AT-1, 61; GD2,93 


$$
\begin{aligned}
& \text { ايلجى كري İlçî garî } \\
& \text {, الس } \\
& \text { Uاولس الس Ûlus }
\end{aligned}
$$

$$
\begin{gathered}
\text { Efğân ulus } \\
\text { آلوغخان اولس Alûç }
\end{gathered}
$$

ان Anâ

Anâ valî
اناو انى İngah
انك Utû
اوتو, Utû

Berkِî utu Utu kol Elçi MWEP, 108; 1.Elçi.
2.Haberci PED, 71; PEDA, 48

Elçilik, sefîrlik. DPPLA, 43

Ulus, halk.. DPPL, 5; PEDA, Büyük, kudretli.. OTIL-2, 278;

45; EPPED, $184 \quad$ DTO, 79; uluş Vilayet, ülke

IML, 50; اولوس ; LO-

aşiretin büyüğ̈̈.. LÇ, 40; اولوس

kavim ümmet.. KT, 223; DTO,

79; millet TS, 2033; olus

oymak, budun, topluluk DS-9,

3279; aşiret, kavim DS-11,

4035; CEAT, 152; HE, 422

Afgan halk1. PED, 41

Mürdüm eriği PEDA, 6

Anne veya baba tarafindan nine DPPL, 6; nine PEDA, 34; EPPED, 185, F; 1.Nine. 2. Büyüme, yetişme (kız). 3. Ahlâklı olma, ahlâklı büyüme. PED, 51

Ailede ninelik makamı. PED, 52

Düğünde veya bir gün sonrasına kadar geline refakat eden kadın. DPPL, 6; EPPED, 185; PED, 72

Ütü PED, 60; Elbise MWEP, 90; PEDA, 42

Elektirikli ütü. PED, 60

Ütülemek. PED, 60 $\begin{array}{llll}3 & 8 & 2 \\ \text { Bir ağaç ve onun yenen meyvesi } & 1 & 13 & 2\end{array}$

AT-1, 152; HE, 8, ?; Gülgiller familyasından.. meyvesi kırmızı, siyah ve sarıdır. OAS-1, 6;

TBAS, 29

Çocuğu olan kadın, anne TS-1, $\quad 1 \quad 1 \quad 2$ 102; Anne, ETDR, 491; anne, mader.. LO-1, 63; anne.. DTO, 37; ana.. OTIL-1, 537; İML, 10; آن KT, 57; ana TaS-1, 1; R-1 226; LÇ, 22; sütanne UTS, 40, U; TS, 92; DLT, 142; CEAT, 169; AT-1, 94; GD-2, 130

üvegi ,Ana makamında آناكا $\quad \begin{array}{llll}1 & 8 & 1\end{array}$ mader daye LÇ, 22; dadı, sütanne UTS, 42

( ) kumaş, deri gibi şeylerin yüzünü düzleme.. LO-1, 217; (TaS-6, 4125; اوتو KT, 187; TS, 2067; (utug) DLT, 642; iti ütü DS-7, 2568; HE, 428; GD-2, 9 
Ûtâk $\quad$ Otak, oda PED, 65

اولجى Ûlçek

اون Ûn

ايثيك آغاسى İşik ağasi

ايبى Aybek

Bâbâ, bâbô

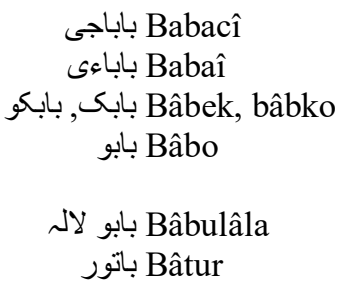

Bacî

Baḳlava

Balkeçî

Bandeçî
Kelepçe PEDA, 45

Yün, iplik

Merasim tertibatçısı PED

Aybek. PED, 68

Baba, efendi, büyüklere saygı ifadesi, torunların dedelere hitabı. DPPL, 9; 1.Baba. 2.Dede. PED, 72; dede PEDA, 49; EPPED, 188

Dede PED, 72

Babalık. PED, 72

Baba. PED, 72

1.İşçi, memur. 2.Asil adam. PED, 72

Düğün ağıtçısı. PED, 72

Bahadırın bozulmuşu DPPL 9; cesur.. PEDA, 49; cesur, kartal EPPED, 188, F;

1.Yiğit. 2.Kahraman, cesur. 3.Batur. PED, 73

Abla

Baklava

Mürîd. PED, 78

1.Dağ kulübesinde yaşayan kişi. 2. Köylü, çiftçi. PED, 78

Büyük çadır ETDR, 499; اوتاق 112

oturacak yer, oda, çadır.. LO-1,

7; tente, oturulan yer.. DTO, 4;

İML, 54; اوتاق oturulan veya ateş yakılan yer.. KT, 185 ; çadır..

TaS-5, 3022; otağ Büyük ve süslü çadır. TS, 1518; اوتاق LÇ, 24; UTS, 25; otâg DLT, 364;

CEAT, 46; çadır DS-9, 3292;

AT-6, 172

(Elcek) Bazı iş aletlerinin

tutacak yeri AT-1, 707

Kus tüyü İML, 93; (يوگ koyun 114

tüyü.. KT, 1565; yün UTS, 43,

H; yün TS, 2208; GD-4, 227

Eşik ağası GD-2, 183; TDVİA- 1992

11,462

Aybek, ağa, zengin, mal sahibi. $\begin{array}{lll}1 & 2 & 2\end{array}$

GD-2, 173

Çocuğu olmuş erkek.. TS-1, $\quad \begin{array}{llll}1 & 1 & 1\end{array}$

187; baba ETDR, 521; LN, 143 ,

F; baba, valid.. LO-1, 225;

OTIL-1, 166; LÇ, 66; KT, 257;

TaS-1, 270, F; UTS, 47, U; TS,

171; AT-1, 176; Gd-2, 228

Yaşayan diyalektlerde batır

batur olarak

kullanılır. HE, 33, T/Mğ?

Abla, büyük kız kardeş.. TS-1, 1112

191; bac1, hanım ETDR, 522;

büyük hemşire, abla.. LO-1,

229; abla, yaşlı kadın DTO, 145;

LÇ, 67; KT, 259; TaS-1, 362;

UTS, 48; TS, 174; GD- 2, 231;

AT-1, 179; GD-2, 231

Çok ince yufkadan arasına

kaymak, fistık, ceviz, badem

gibi şeyler konulan tatli. TS-1,

205; I بقلوbaklava.. ETDR, 540;

..kesilmiş tatlu hamur LO-1,

246; TaS-1, 384; KT, 272; TS,

188; DS-9, 3381; AT-1, 192;

GD-2, 255

$\begin{array}{lll}3 & 1 & 2 \\ 3 & 1 & 2 \\ 3 & 1 & 1 \\ 1 & 8 & 1 \\ 3 & 8 & 1 \\ 1 & 8 & 2\end{array}$

2

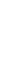

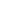

.

.




\begin{tabular}{|c|c|c|c|c|}
\hline Banḍeçi & 1. Kurda yaşayan kişi. 2. & & 2 & 8 \\
\hline بيو Bebû & $\begin{array}{l}\text { Anne veya yaşlı kadın. PED, } \\
80\end{array}$ & & 1 & 1 \\
\hline Bahrî urdu & Deniz ordusu PED, 19 & $\begin{array}{l}\text { Bahriyye, deniz kuvvetleri. AT- } \\
1,263\end{array}$ & 3 & 4 \\
\hline Barma & $\begin{array}{l}\text { Delik açmaya yarar bir alet, } \\
\text { burgu DPPL, 13; burgu, } \\
\text { kuyu açmaya yarar alet PED, } \\
\text { 89; PEDA, } 66\end{array}$ & $\begin{array}{l}\text { Burma, Burgulu alet İğdiş etme.. } \\
\text { TaS-1, } 709 \text { burmak işi..TS, 328; } \\
\text { ( بورغو delik açmaya yarar alet } \\
\text { DTO, 166; بور Burgu, vida } \\
\text { ETDR, 545; (burma) burmak } \\
\text { TaS-1, } 709\end{array}$ & 1 & 14 \\
\hline Barğû & 1.Burgu. 2.Süngü. PED, 88 & $\begin{array}{l}\text { Delik açmaya yarar alet. AT-1, } \\
\text { 329; GD-2, } 286\end{array}$ & 1 & 14 \\
\hline بري اردو Berrî urdu & Kara ordusu PED, 19 & Kara, asâkir-i berriyye KT, 291 & 3 & 4 \\
\hline بوزه Bûza & $\begin{array}{l}\text { Mayalanmış likör DPPL, 16, } \\
\text { F; 1.Mayalı içecek. } \\
\text { 2.Eksimis viyecek. DEP, } 103\end{array}$ & $\begin{array}{l}\text { Boza. GD-2, 337; AT-1, 307, } \\
\text { T/F? }\end{array}$ & 1 & 3 \\
\hline شuşḳ̂ab & Tabak PED, 93 & Tabak, tepsi vb GD-2, 292 & 1 & 5 \\
\hline بندوق Bandûk & Tüfek. DPPL, 15 & 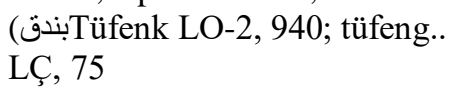 & 1 & 6 \\
\hline بورغو Burğu & $\begin{array}{l}\text { Sigara piposu PED, 102; } \\
\text { burgu PEDA, } 64-79\end{array}$ & $\begin{array}{l}\text { Dönerek tahta vs delmeye yarar } \\
\text { alet.. KT, 309; AT-1, } 329\end{array}$ & 1 & 5 \\
\hline $\begin{array}{l}\text { بuğma } \\
\text { بو غموره Buğmûra }\end{array}$ & $\begin{array}{l}\text { Boğaz iltihabı, ödem PED, } \\
\text { 103; difteri PEDA, } 79\end{array}$ & $\begin{array}{l}\text { (Boğmaca) Boğaz hastalığı AT- } \\
1,365 ; \text { GD- } 2,345\end{array}$ & 1 & 15 \\
\hline 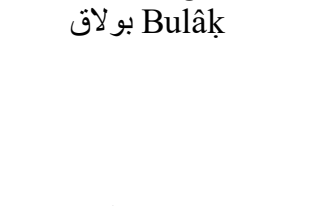 & $\begin{array}{l}\text { Bir tür ziynet eşyası. DPPL, } \\
16, \mathrm{H}\end{array}$ & $\begin{array}{l}\text { Bulaki, buruna takılan ziynet.. } \\
\text { OTIL-1, 148; haşarı at.. IML, } \\
\text { 22; بلاك burun kanadı LÇ, 223; } \\
\text { kaynak, pınar TS, 321; Sirtı } \\
\text { geniş at DLT, 204; GD-2, } 312\end{array}$ & 1 & 10 \\
\hline Buzhah بخذ & $\begin{array}{l}\text { 1.Küçük bez. 2.Eşya kabı. } \\
\text { DPPL, } 11 ; \text { PED , } 94\end{array}$ & 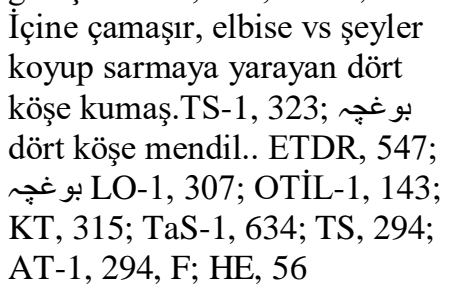 & 1 & 5 \\
\hline بكاول Bekâvel & $\begin{array}{l}\text { Aşçı, gözetici. DPPL, 14, F; } \\
\text { aşçı PED, 95; EPPED, 193, } \\
\text { F }\end{array}$ & $\begin{array}{l}\text { (بوكاول Türkçede çeşnigir LO-1, } \\
\text { 311; çeşnicibaş1 DTO, 158; } \\
\text { OTILL-1, 74; çşsnigir, divan } \\
\text { beyi.. LÇ, 75; GD-2, } 301\end{array}$ & 1 & 9 \\
\hline Bulğâr & Bulgar. PED, 96 & $\begin{array}{l}\text { (بلغارى) Bir cins Rus derisi.. } \\
\text { ETDR, 541 Tabaklanmış deri } \\
\text { DTO, 176; bir Türk kavmi.. LO- } \\
\text { 1, 316; ..telatine (deri) dahi itlak } \\
\text { olunur LÇ, 85; TS, 323; } \\
\text { Herkes-ce bilmen bir Turk kenti } \\
\text { DLT, 205; esasen Erdel dağları } \\
\text { cihetin-de sakin akvam } \\
\text { tatariyyeden iken b'dehu } \\
\text { Rumeli.. KT, 302; Bulgar milleti } \\
\text { AT-1, 323; HE, 63 }\end{array}$ & 1 & 7 \\
\hline بندق Bandûk & Tüfek. PED, 98 & $\begin{array}{l}\text { (بندق)Tüfenk LO-2, 940; tüfeng.. } \\
\text { LÇ, } 75\end{array}$ & 1 & 6 \\
\hline
\end{tabular}




\begin{tabular}{|c|c|c|c|c|}
\hline Butî & Deve yavrusu. PED, 101 & $\begin{array}{l}\text { Çocuk, hayvan yavrusu.. DTO, } \\
\text { 160; OTİL-1, 165; yavru, bala.. } \\
\text { LÇ, 76; botu Deve yavrusu. } \\
\text { DLT, 198; بوتاGD-2, } 328\end{array}$ & 1 & 11 \\
\hline Bîbî & $\begin{array}{l}\text { Evli kadın, abla. DPPL, 17, } \\
\text { H; PED, } 105\end{array}$ & $\begin{array}{l}\text { Babanın kız kardeşi, hala. TS-1, } \\
\text { 289; hanım, nikahlı hanım DTO, } \\
\text { 181; nine.. OTILL-1, 110; nene, } \\
\text { büyük valide, hanım efendi.. } \\
\text { LÇ, 88; hanım, hanım efendi } \\
\text { TaS-1, 543; babanın kız kardeşi, } \\
\text { hala TS, 262; GD-2, } 379\end{array}$ & 1 & 1 \\
\hline Bayrağvala & Bayraktar PED, 111 & $\begin{array}{l}\text { Bahadurlık.. OTIL-1, 90; } \\
\text { bahadırlık KT, 326; bahadırlık } \\
\text { TS, } 182\end{array}$ & 3 & 4 \\
\hline $\begin{array}{l}\text { Bayrağ } \\
\text { Beyrâğ }\end{array}$ & $\begin{array}{l}\text { Bayrak MWEP, 61; DPPL, } \\
\text { 18, A; bayrak, afiş, işaret } \\
\text { afişi PED, 110; PEDA, 82; } \\
\text { EPPED, 197, A }\end{array}$ & $\begin{array}{l}\text { Bir milletin, belli bir topluluğun } \\
\text { veya bir kuruluşun simgesi } \\
\text { olarak kullanılan, renk ve } \\
\text { biçimle özelleştirilmiş, } \\
\text { genellikle dik dörtgen biçiminde } \\
\text { kumaş. TS-1, 249; bayrak, } \\
\text { sancak ETDR, 551; küçük } \\
\text { bayrak DTO, 183; bayrak.. } \\
\text { OTİL-1, 73; LÇ, 90; بايراقKT, } \\
\text { 278; TS, 227; GD-2, 385; AT-1, } \\
223\end{array}$ & 1 & 2 \\
\hline Beg بيگ & Bey PED, 113 & 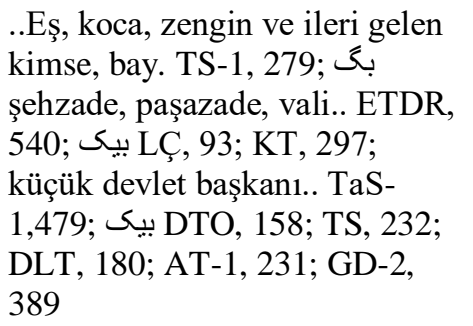 & 1 & 1 \\
\hline 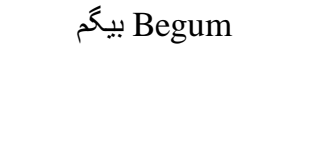 & $\begin{array}{l}\text { Begum, Hanım PED, 113; } \\
\text { PEDA, } 84\end{array}$ & $\begin{array}{l}\text { Hint prenseslerine verilen } \\
\text { unvan. TS-1, 255; hanım, hanım } \\
\text { sultan DTO, 192; بيكيم LÇ, 93; } \\
\text { TS, 232; AT-1, 231; GD-2, } 411\end{array}$ & 1 & 1 \\
\hline بشقاب Peşkââ & $\begin{array}{l}\text { Tepsi, masa örtüsü veya yer } \\
\text { bezi. DPPL, 24; PED, } 140\end{array}$ & Tabak, tepsi vb GD-2, 292 & 3 & 5 \\
\hline Propagandçî̂ يُروياگندج & Propagandacı. PED, 132 & & 2 & 9 \\
\hline بوست باش Postabaşî & $\begin{array}{l}\text { Gümük ve posta şefi PED, } \\
154\end{array}$ & & 2 & 9 \\
\hline Postînçî & Postçu, derici PED, 154 & Postin OAS-7, 2365 & 2 & 9 \\
\hline 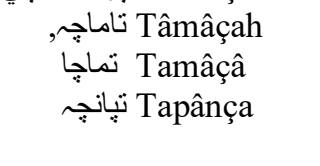 & $\begin{array}{l}\text { (تامانج Tabanca MWEP, 137; } \\
\text { tabanca, tokat.. DPPL, 38, A; } \\
\text { PED, 203; tabanca PEDA, } \\
\text { 140; EPPED, } 217\end{array}$ & $\begin{array}{l}\text { (طبانج) Tabanca ETDR, 796; } \\
\text { (طبانجـ tabanca KT, 856; } \\
\text { tabanca.. OTİL-2, 252; TS, } \\
\text { 1879; HE, 391; GD-3, } 339\end{array}$ & 1 & 6 \\
\hline Tak & $\begin{array}{l}\text { Tek, çift olmayan, eşsiz. } \\
\text { PED, } 171\end{array}$ & Tek, yalnız, issiz. SN & 1 & 14 \\
\hline تبليغجي Tebliğçî & Propogandacı PED, 174 & Tebliğ KT, 378; OAS-9, 2796 & 3 & 9 \\
\hline تينگ Tupengçe & $\begin{array}{l}\text { Tüfenk DPPL, 40, F; PED, } \\
198\end{array}$ & Tüfek ETDR, 593 & 3 & 6 \\
\hline تينگسـاز Tupengsâz & Tüfenk ustası PED, 198 & $\begin{array}{l}\text { Tüfekçi.. OAS-9, 2916; } \\
\text { (Tüfengçi) Tüfeng imal eden } \\
\text { san'atci. KT, } 323\end{array}$ & 3 & 9 \\
\hline
\end{tabular}




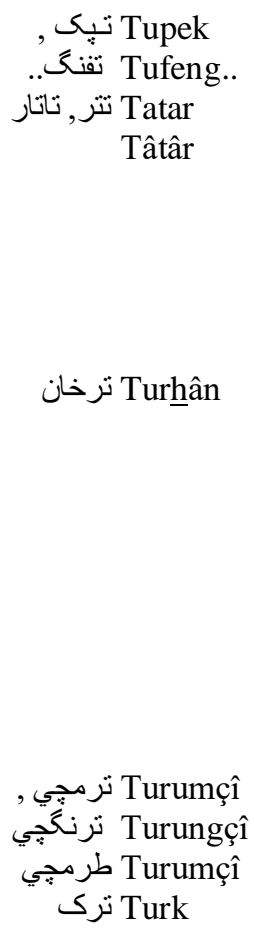

Turkman

$$
\begin{gathered}
\text { Turkmanî } \\
\text { تركمانى Turkmane } \\
\text { تركمان Turke }
\end{gathered}
$$$$
\text { Turkî }
$$$$
\text { Tasmah }
$$

Tüfek. DPPL, 40; MWEP, Top dișı silah..ETDR, 593; تفنگ $1 \quad 6 \quad 2$ 166; PED, 198; EPPED, 216 Tüfek KT, 422: TS, 2016, F Tatar PED, 175; PEDA, 135 Ulak, Tatar ETDR, 566; Moğol 11472 tavayifin-den bir küçük aşiret.. LO-1, 381; Tatar halkı OTİL-2, 133; LÇ, 98; mektub nakleden seri-ul hareke sâ'i.. KT, 370; TS, 1918; bir Türk kavmi DLT, 540; postac1 DS-10, 3842

Eskiden vergiden ve gümrükten (ترخان Bir türk kabilesi.. DTO, muaf kişi PED, 183; PEDA, 318; (ترخان) kadim Türk 147; EPPED, 214

uluslarında imtiyazlu ve tekalifden ma'fu olan ayan-i agâvât LO-1, 396; (ترخان) ..imtiyazlı kimse.. LÇ, 108; mükellefatdan muaf ve mumtaz berayadan bulunan asil ve şerif kimse KT, 881; GD-2, 460

Trampetçi, borazancı PED, Trampetçi, trampet çalan. OAS- $3 \quad 9 \quad 2$ 185 9, 2899

Trampetçi, çalgııı PED, 494

1. Turk. 2. Soyguncu. 3. Genç ve yakışıklı erkek. DPPL, 35, F; 1.Türkçe konuşan. 2.Türk. 3.Asker. 4.Yakışıklı genç. PED, 184

Bir Asya eyaleti ETDR, 582;

Türkmen PED, 185; PEDA, 148

Türkmen insanı. PED, 185

Türkmen kadını. PED, 185 1. Türk kadını. 2. Sevgili, maşuk, mahbûb. PED, 185; güzel k1z PEDA, 148 1. Türke ait. 2.Türk PED, 185; PEDA, 148; Türk insanı. PIQ, 112

Tasma, kemer MWEP,167; DPPL, 37, H; 1.Deri kemer. 2.Kayış PED, 191; kayış, sırım, kemer PEDA, 148

Türk insan1.. ETDR, 582, Ar; $3 \quad 3 \quad 2$ türk ümmetine veya lisanını mensub KT, 400; 1.türkle ilgili, 2.Türkçe TS, 2021

(طاسمـTutma veya bağlamaya yarar şerit, ip. ETDR, 794; deri kemer.. DTO, 216; deri kayış, kemer.. OTIL-2, 132, F; تاسم
Zamme ile asl olan kadim üç sülalenin biri..LO-1, 394; yiğit, cesur DTO, 213; turk milleti.. OTILL-2, 225; ..Nuh'un üç oğlundan Yafes'e işaretdir ki.. LÇ, 108; asya kıtasında şimal garbi cihetinde müiteşir bir büyük ümmet.. KT, 399; OK, 17; TS, 2020; DLT, 606; GD-2, 483; CEAT, 537

Türk ümmeti şu'abatından bir büyük kavm ki esaseen köçebe halinde yaşayub.. KT, 399; LÇ, 108; TS, 2021; DLT, 607; GD2, 498 kolan kayışı.. (LÇ, 100; dilinmiş kayış TaS-5, 3767; طسم KT, 884; تاسه LO-1, 383; TS, 1913; bel kemeri, takunya kayış1.. DS- 


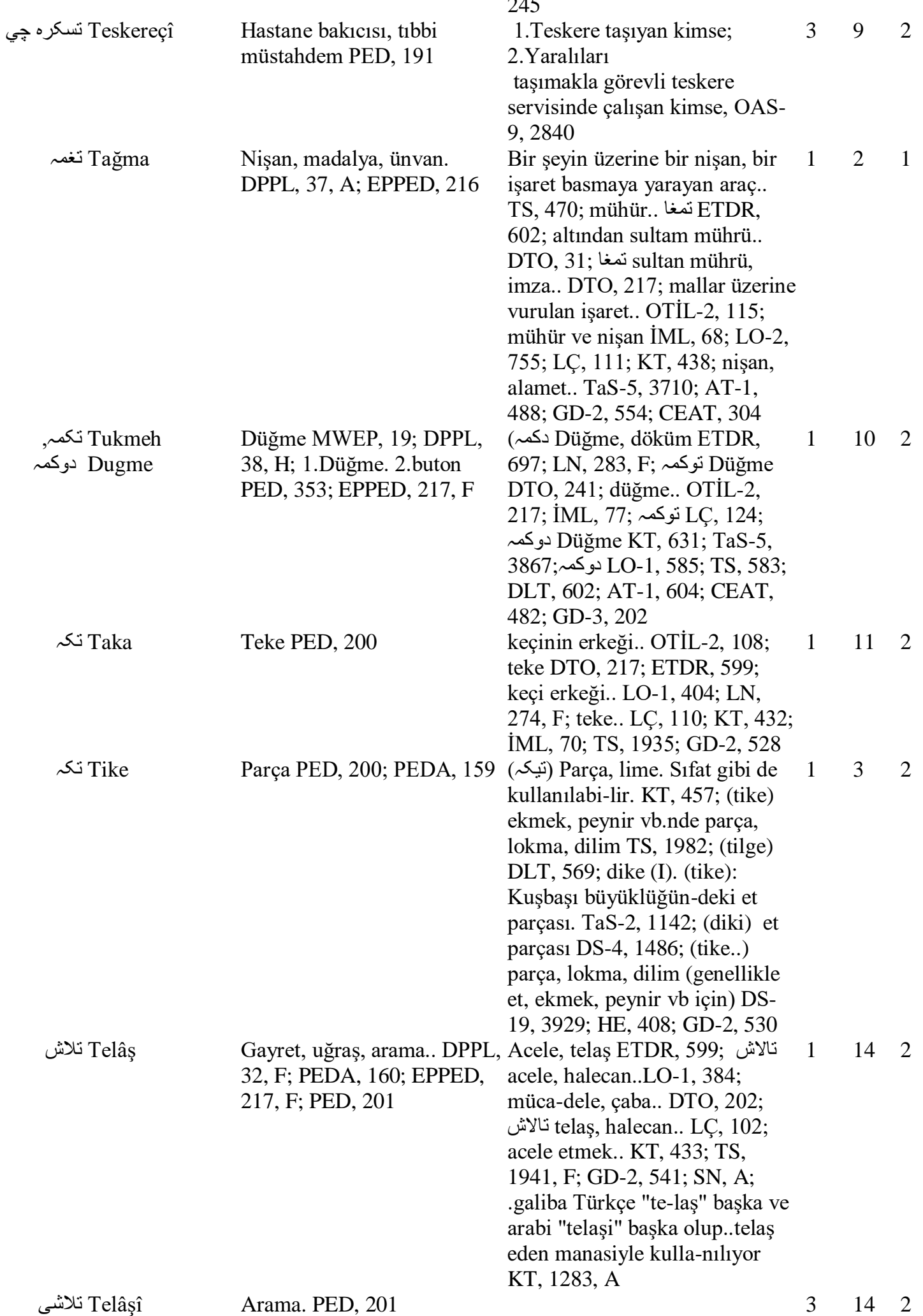

10, 3818; HE, 396, Mğ GD-1,

2.Yaralıları

taşımakla görevli teskere

9,2840 


\begin{tabular}{|c|c|c|c|c|}
\hline Telfonçî تلفونجي & Telefoncu PEDA, 161 & $\begin{array}{l}\text { 1.Telefon düzeni kuran veya } \\
\text { telefon onaran kimse; } 2 \text {.Santral } \\
\text { memuru, santralci: Telefoncu } \\
\text { k1z, OAS- } 9,2812\end{array}$ & 3 & 9 \\
\hline Telgrafçî & $\begin{array}{l}\text { Telgrafçı PED, 202; PEDA, } \\
161\end{array}$ & Telgraf görevlisi OAS-9, 2815 & 3 & 9 \\
\hline تماثـاجى Temâşâçî & $\begin{array}{l}\text { Ortalığı karıştıran kişi } \\
\text { MWEP, 192; gösterici, } \\
\text { temaşacı PED, 203; PEDA, } \\
162\end{array}$ & $\begin{array}{l}\text { (temâşâ-ger) Seyirci. OAS-9, } \\
2818\end{array}$ & 3 & 8 \\
\hline تمن Tumen & $\begin{array}{l}\text { Tümen, asker, bölük, 20.. } \\
\text { DPPL, 39, F; 1.Bir kabile } \\
\text { adı. 2.Kalabalık, yığın. } \\
\text { 3.Bölük bölük. 4.Parada } 20 \text {. } \\
\text { PED. } 205\end{array}$ & $\begin{array}{l}\text { (تومان On bin kişilik bölük } \\
\text { ETDR, 610, F; تومان on bin.. LÇ, } \\
\text { 126; } 10 \text { bin, pek çok, firka TaS- } \\
\text { 5, 3870; تومان KT, 454; LO-1, } \\
\text { 416; OK, 17; TS, 2018; bir şeyin } \\
\text { çok olan1 DLT, 603; CEAT, } \\
\text { 507; GD-2, } 632\end{array}$ & 1 & 4 \\
\hline Tanburçî & $\begin{array}{l}\text { 1. Tambur sanatçısı. 2. Tanbur } \\
\text { çalan kişi PED, 205; PEDA, } \\
164\end{array}$ & $\begin{array}{l}\text { (طنبوره t) tanbure denilen } \\
\text { çalgıı1 yapan adam KT, 887; } \\
\text { tanbur çalan.. OTİL-2, 116; TS, } \\
1897\end{array}$ & 3 & 9 \\
\hline Torba & $\begin{array}{l}\text { At burunluğu, heybe, dilenci } \\
\text { torbası DPPL, } 39, \mathrm{Pş}\end{array}$ & $\begin{array}{l}\text { Çanta ETDR, 607; طوربـ Kildan } \\
\text { olmayan küçük çuval KT, 895; } \\
\text { طورب LO-2, 778; TS, 1996; } \\
\text { OAS-9, 2891; GD-2, } 592\end{array}$ & 1 & 5 \\
\hline Top توب & $\begin{array}{l}\text { Top, siçrama MWEP, 10; } \\
\text { DPPL, 40; PED, 209; PEDA, } \\
\text { 167; EPPED, } 219\end{array}$ & $\begin{array}{l}\text { Top ETDR, 802; طوب top.. LO- } \\
\text { 2, 769; توب top.. DTO, 220; top.. } \\
\text { OTIL-2, 250; yuvarlak ve } \\
\text { mecmu' olan şeyler.. LÇ, 112; } \\
\text { طو top.. KT, 888; TS, 1990; } \\
\text { GD-2, 596; OAS-9, } 2881\end{array}$ & 1 & 6 \\
\hline Top توب Top & $\begin{array}{l}\text { Parça, adet, yı ̆̆ın tekstil } \\
\text { PED, 209; PEDA, } 167\end{array}$ & $\begin{array}{l}\text {..5.Kumaş, kâğıt gibi şeylerin } \\
\text { belli miktar-daki bağı. OAS-9, } \\
2881\end{array}$ & 1 & 5 \\
\hline توب بازي Top bâzî & $\begin{array}{l}\text { Top oyunu PED, 209; } \\
\text { PEDA, } 167\end{array}$ & & 3 & 8 \\
\hline Tophâneh توب خان To & $\begin{array}{l}\text { Tophane PED, 209; PEDA, } \\
167\end{array}$ & $\begin{array}{l}\text { (طويخانـ Tophane ETDR, 802; } \\
\text { طوبخان topçu askerinin idare-i } \\
\text { merkeziyesi.. LO-2, 770; } \\
\text { cephane, tophane OTİL-2, 252; } \\
\text { طوبخان tophane.. KT, 889; TS, } \\
\text { 1991; OAS-9, } 2884\end{array}$ & 3 & 12 \\
\hline Tup sazî توب سازى Tu & Top imali. PED, 209 & & 3 & 14 \\
\hline Topçî & $\begin{array}{l}\text { Topçu PED, 209; PEDA, } \\
167\end{array}$ & 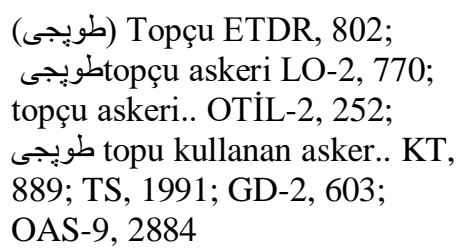 & 1 & 4 \\
\hline Tûpek توبكى & $\begin{array}{l}\text { Tüfek, küçük top } \\
\text { MWEP,167; } \\
\text { EPPED, 219; PED, } 209\end{array}$ & $\begin{array}{l}\text { Top diş1 silah..ETDR, 593; تفنگ } \\
\text { TüfekKT, 422: TS, 2016, F; } \\
\text { SN,? }\end{array}$ & 1 & 6 \\
\hline Tûpekvala توِِى و الا & Tüfekçi PED, 209 & & 3 & 4 \\
\hline تفنگ Tufeng & Tüfek. PED, 198 & & 1 & 6 \\
\hline Tufeng تفنگج Tu & Ufak tüfek; tabanca. PED, & & 3 & 6 \\
\hline
\end{tabular}




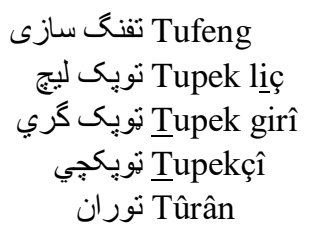

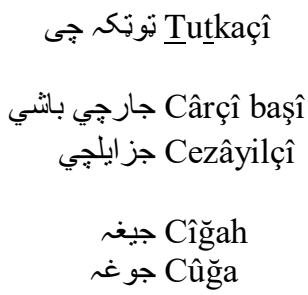

198

Tüfek imali. PED, 198

Dipçik. PED, 209

Tüfekçilik PED, 229

Tüfekçi PED, 229

Tüfekçi. GD-2, 449

Turan PED, 210; PEDA, 169 Eski İraniler tarafindan

Türkistan ve Tataristan

cihetlerine verilen isim LN, 296,

F; kadimde dağlık.. LO-1, 412;

Türkistan dağlığı.. LÇ, 115; KT, 449; TS, 2008, F

1.Kılıç. 2.Bakır para, yarım anna. DPPL, 40, Pş

Kale IML, 76; kraliyet ailesi

DTO, 224, kanun, nizam KT, 449; hanzade, bekzade..; LÇ, 115; töre Bir toplulukta benimsenmiş, yerleşmiş davranış ve yaşama biçimlerinin, kuralların, görenek ve geleneklerin, ortaklaşa alıșkanlıkların, tutulan yolların bütünü. TS, 2000

Yüklük, elbise dolabı PED, 213

Döşek ve diğer serilen şeylerin hanesi.. LÇ, 119

Döşek MWEP, 105; DPPL， Döşek. TS-1, 636; دوشك Döşek 1152 40, F; PEDA, 170; 1.Döşek. ETDR, 696; döşek, serilen 2.Katlanabilir kilim PED, 213; EPPED, 219, F şey..DTO, 234; OTİL-2, 256; İML, 75; LÇ, 119; TaS-5, 3844, F; دوشك KT, 626; دوشك LO-1, 583; TS, 570; DLT, 587; AT-1, 589; CEAT, 563; GD-2, 617

Tuğ, bayrak. DPPL, 40; bayrak.. PED, 213/496; Hotaz ve at kuyruğundan sancak 1 ucuna ve miğfer depesine PEDA, 171; EPPED, 219, F takılan tereke.. LO-2, 784; sancak ve bayrak ucuna takilan tüy.. LÇ, 120; paşalara rütbelerine göre 1,2 ve 3 adedinde olarak verilen at kılından sorguç KT, 452, F; TaS-5, 3847; توغ ETDR, 608; TS, 2005; tûg DLT, 588; CEAT, 464; GD-2, 618

Çırak, şakirt, hekim yamağı. PED, 229

Baş tellal PED, 235

Silahşör, Tüfek kuşanmış asker PED, 241

1.Başlığa takılan değerli bir ziynet, sorguç. 2.Kuş ibiği PED, 253; taç PEDA, 135

Hakana mahsus sorguç şah1.. 292 292

LO-1, 437; جغا hakanlara mahsus taç, sorguç şahı LÇ, 140; جيغا sorguç, çelenk.. KT, 477; DTO, 306; GD-3, 9

Çarık PEDA, 212; PED, 255 Köylülerin giydiği ayakkabı ki.. $1 \quad 10 \quad 2$ KT, 498; GD-3, 23; AT-1, 412 


\begin{tabular}{|c|c|c|c|c|}
\hline $\begin{array}{l}\text { جُاغٌ Çâăg } \\
\text { جاقٌ Çâk }\end{array}$ & $\begin{array}{l}\text { Sağlam, zinde..DPPL, 54, } \\
\text { Pş; 1.Zinde. 2.Şişman, obez. } \\
\text { 3.Hareketli. PED, 255; } \\
\text { Şişman, obez PEDA, 212; } \\
\text { EPPED, } 233\end{array}$ & $\begin{array}{l}\text { Sağlıklı, zinde.. DTO, 276; } \\
\text { çakki, dürüst, düzgün.. OTİL-2, } \\
350 \text {; TaS-1, 259; çaq Bir şeyin } \\
\text { kesin ve öz halini vurgulayan bir } \\
\text { sözcük DLT, 222; CEAT, 405; } \\
\text { GD-3, } 25\end{array}$ & 1 & 14 \\
\hline 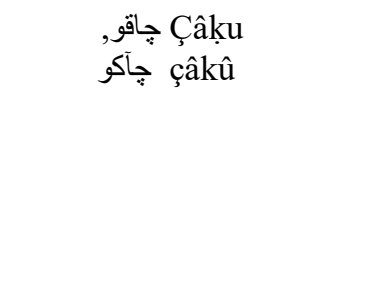 & $\begin{array}{l}\text { Çakı MWEP, 94; DPPL, 54, } \\
\text { F; PED, 255; PEDA, 212; } \\
\text { EPPED, 233, F }\end{array}$ & $\begin{array}{l}\text { Açılıp kapanan bir veya birkaç } \\
\text { ağızlı küçük cep bıçağ1. TS, } \\
\text { 383; جاقى cep bıçağ1.. ETDR, } \\
\text { 632; جاقى aç1lıp kapanan ufak } \\
\text { bıçak.. LO-1, 461; OTİL-2, 350; } \\
\text { جT, 500; AT-1, 398; GD-1, } \\
\text { 303, Mğ }\end{array}$ & 1 & 5 \\
\hline جيبى جاقو Cebî çâḳu & Cep çakısı PEDA, 212 & & 3 & 5 \\
\hline جاقوسناز Çâkusâz & Çakıcı, çakı ustası PED, 255 & & 3 & 9 \\
\hline جاقوسازى Çâkusâzî & Çak1 imali. PED, 255 & & 3 & 14 \\
\hline ج Çat & $\begin{array}{l}\text { 1.Çatı. 2.Tavan. 3.Tente. } \\
\text { 4.Binanın yapıs1. 5.Güverte } \\
\text { PED, 258; çatı PEDA, } 214\end{array}$ & 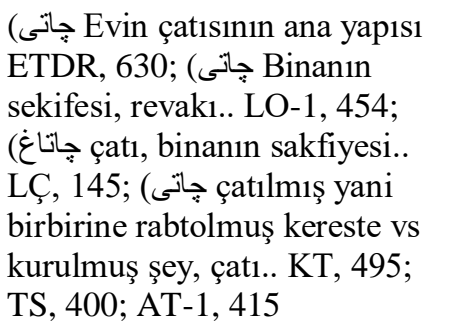 & 1 & 12 \\
\hline 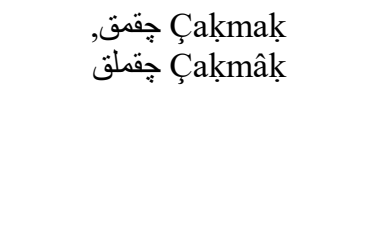 & $\begin{array}{l}\text { Çakmak DPPL, 57; PED, } \\
263 ; \text { PEDA, 218; EPPED, } \\
236\end{array}$ & $\begin{array}{l}\text { (جاقمق Çakmak.. ETDR, 631; } \\
\text { çakacak alet LO-1, 461; OTILL- } \\
\text { 2, 360; IML, 24; DTO, 278; } \\
\text { (KT, 500; (جاقماق LC7, 14S, } \\
\text { 384; DLT, 223; CEAT, 408; } \\
\text { AT-1, 399; GD-3, } 80\end{array}$ & 1 & 5 \\
\hline 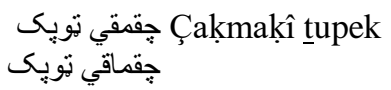 & $\begin{array}{l}\text { Çakmaklı tüfek PED, 229; } \\
\text { PEDA, } 184\end{array}$ & & 3 & 6 \\
\hline 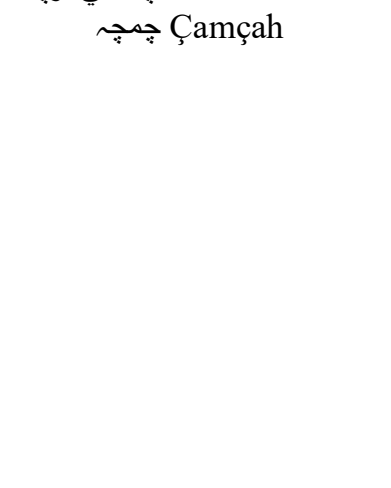 & Çömçe, kaşık. PED, 265 & 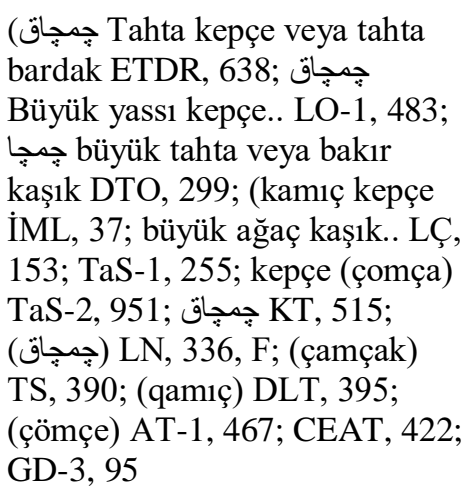 & 1 & 5 \\
\hline جناق Çanâk & Lâdes kemiği PEDA, 220 & $\begin{array}{l}\text { Çanak, oyulmuş kab.. GD-3, } \\
\text { 101; AT-1, 472; yayvan toprak } \\
\text { kab.. KT, } 504\end{array}$ & 1 & 5 \\
\hline جانت Çânta & Çanta. PED, 256 & Çanta. AT-1, 406 & 1 & 5 \\
\hline جو غو غا Çuga & Çuha. PED, 269 & $\begin{array}{l}\text { (جوقت Bir tür kumaş ETDR, 640; } \\
\text { جوق Kalın kumaş, havlu.. LO-1, } \\
\text { 496; kürk ceket DTO, 294;خوخ KT, 519; çuha } \\
\text { LN, 337, F; جوخ KT } \\
\text { (çuka) TaS-2, 957; TS, 454; } \\
\text { (çug) Heybe, bohça DLT, 243; } \\
\text { AT-1, 471, F?; GD-3, } 110\end{array}$ & 1 & 10 \\
\hline
\end{tabular}




\begin{tabular}{|c|c|c|c|c|}
\hline جو غتا Çuğtâ & $\begin{array}{cc}\text { Çağatay kabilesi. PED, } 262 & \text { (ى) } \\
& \text { oğ } \\
& 1, \\
& \text { oğ } \\
& . . \mathrm{B} \\
& \mathrm{Ta} \\
& \text { ler } \\
& \text { söy } \\
& \text { lisa }\end{array}$ & $\begin{array}{l}\text { جغت) Çengiz Hanın üçüncü } \\
\text { lu ve de bir meliki olup.. LO- } \\
\text { 437; Cengiz Hanın üçüncü } \\
\text { lu ismidir.. LÇ, 140; (جغاتاى) } \\
\text { uhara ve Hive hakanlarıyla } \\
\text { şkend ve Semerkand cihet- } \\
\text { ine sakin kavme ve oralarda } \\
\text { ylenip yazılan şarki Türk } \\
\text { anına verilen isim.. KT, } 47\end{array}$ & 1 & 7 \\
\hline جو غتى Çağatay & \multicolumn{2}{|l|}{$\begin{array}{l}\text { Çağatay hanedanna mensub. PED, } \\
262\end{array}$} & 1 & 7 \\
\hline جֶغ Çiga & $\begin{array}{l}\text { Çık, kaybol! Köpek kovalamada } \\
\text { istimal olunur. PED; } 263\end{array}$ & $\begin{array}{l}\text { İçerden dişarıya hareket } \\
\text { etmek. AT-1, } 457\end{array}$ & 1 & 8 \\
\hline ج̧ول Çöl & Çöl PEDA, 223; PED, 270 & $\begin{array}{l}\text { Çöl, verimsiz arazi ETDR, } \\
\text { 641; çöl, sahra, beyaban.. } \\
\text { LO-1, 497; جو susuz çöl } \\
\text { DTO, 297; susuz yer, sahra.. } \\
\text { OTİL-2, 386; çöl, sahra, } \\
\text { beyaban.. LÇ, 157; KT, 523; } \\
\text { çöl OK, 12; çöl TS, 450; } \\
\text { (çöl) çölistan AT-1, } 467\end{array}$ & 1 & 12 \\
\hline Çokidar & $\begin{array}{l}\text { Muhafiz, bekçi DPPL, 59, H; } \\
\text { PEDA, 223; PED, } 270\end{array}$ & $\begin{array}{l}\text { (جوقدار Ayak hizmetinde } \\
\text { bulunan çuha elbiseli yahud } \\
\text { çuhadan olan perdenin } \\
\text { haricinde emre muntazır } \\
\text { bulunan hademe ki vaktiyle } \\
\text { bir sinıf-1 mahsus teşkil } \\
\text { ederlerdi. Kapı çakidarı.. } \\
\text { KT, 521; LO-2, } 857\end{array}$ & 3 & 9 \\
\hline 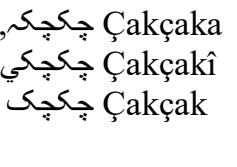 & $\begin{array}{l}\text { Ellerin virbirine vurlmasıyla } \\
\text { çıkan ses, alkış sesi DPPL, 57, } \\
\text { Pş; PED, 263; alkış PEDA, 218; } \\
\text { PED, } 262\end{array}$ & $\begin{array}{l}\text { Çakçakçi, insanları hoş } \\
\text { tutan.. OTİL-2, 360; GD-3, } \\
76\end{array}$ & 1 & 14 \\
\hline جֶم Çekme & $\begin{array}{l}\text { 1.Çizme. 2.kısa ceket. PED, } \\
\text { 264; Çizme, bot. DPPL, } 57\end{array}$ & $\begin{array}{l}\text { Bot veya çizme DTO, 285; } \\
\text { Çizme.. LÇ, 5; çizme.. LÇ, } \\
\text { 209; çekilen veya çekilmiş } \\
\text { şey.. KT, 514; 1..6.İş } \\
\text { yaparken giyilen bir tür } \\
\text { şalvar TS, 409; çizme DS, } \\
\text { 1115; GD-3, } 84\end{array}$ & 1 & 10 \\
\hline 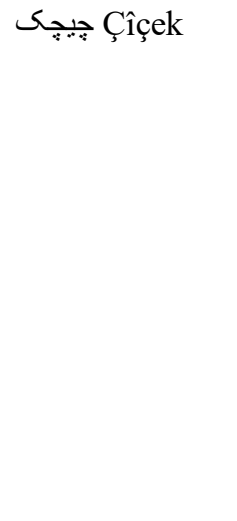 & $\begin{array}{l}\text { 1.Su çiçeği. 2.Meyve } \\
\text { ağaçlarında } \\
\text { görülen bir hastalık. PED, 271; } \\
\text { su çiçeği PEDA, } 224\end{array}$ & $\begin{array}{l}\text { Çiçek, çiçek hastalı̆̆ı.. } \\
\text { ETDR, 641; maruf hastalık, } \\
\text { su çiçeği.. LO-1, 501; (çiçek } \\
\text { DTO, 302; çiçek IMML, 25; } \\
\text {..çiçek, çiçek illeti.. LÇ, 16; } \\
\text { 1...3.insanın bedeni üzerinde } \\
\text { poturak çiçek gibi çıbanlar } \\
\text { açan maruf maraz.. KT, 526; } \\
\text { TS, 432; kızamık ya da çiçek } \\
\text { hastalığı-na verilen ad DLT, } \\
\text { 26; (çeçek çiçek hastalı-ğı } \\
\text { DS, 1105; CEAT, 400; GD- } \\
\text { 3, } 57\end{array}$ & 1 & 15 \\
\hline
\end{tabular}




\begin{tabular}{|c|c|}
\hline جيجّكى Çîçekî & $\begin{array}{l}\text { Çiçek bozuğu MWEP, 139; } \\
\text { PEDA, } 224\end{array}$ \\
\hline Hâzirbaş حاضرباش & Muhafiz, emir eri PEDA, 22 \\
\hline Hamâmçî حمامجي & $\begin{array}{l}\text { PED, } 293 \\
\text { Hamamc1 PEDA, } 243\end{array}$ \\
\hline Hatun & Hatun \\
\hline
\end{tabular}

خاقان Hakan

خان

خان ملا Han mula خانو

Han DPPL, 62; MWEP, 101; bey PEDA, 248; EPPED, 241
Bot veya çizme DTO, 285; 3

152 Çizme.. LÇ, 5; çizme.. LÇ, 209; çekilen veya çekilmiş şey.. KT, 514; 1..6.İş yaparken giyilen bir tür şalvar TS, 409; çizme DS, 1115

Hazır LO-1, 515; Hazır KT, 244 536; Hazır ETDR, 644

Bir hamam idare eden adam $2 \quad 9 \quad 2$ KT, 558; hamam işleten kimse OAS-3, 990

Kadin ETDR, 662; LN, 367, $1 \quad 8 \quad 2$ F; türkçede hâdun, seyyide, kadın.. LO-1, 532; mevkice yüksek kadın DTO, 312; erkek zıddı. OTIL-2, 334; katun İML, 39; LÇ, 166; kadın.. KT, 565; TaS-4, 2354; kadın.. TS, 858; AT-2, 274, Mğ; CEAT, 602

Sultan, padişah ETDR, 664; 122 LN, 369, A; Çince Huhank kelimesinden Türkçeye geçmiştir.. LO-1, 535; hanlar hanı, Çin hükümdarlarına verilen unvan DTO, 312; IML, 32; aslı huhankdır.. LÇ, 166; aslı çin hükümdarlarının.. KT, 569; TS, 830; GD-3, 141 han PED, 305; zengin, varlıklı,

Sultan, emir, efendi ETDR, 1

664, F; Türk sultan1.. LN, 371, F; tatardan evvel Çine müstevli olan etrak muluki ol unvanı takınmış ve her ulus büyügüne han denmiştir.. LO-1, 536; emirler için verilen bir unvan DTO, 312; şark devletlerinde arta asırdaki mutlak hakim olan kişinin unvanı.. OTIL2, 331; İML, 95; LÇ, 166; TaS-1,479, F; KT, 570; TS, 841; DLT, 645; AT-2, 248; CEAT, 630; GD-3, 141

Han molla, baş molla. PED, 305 Hanımefendi, hanım PED, 305 $\begin{array}{llll} & 3 & 9 & 2 \\ \text { (خانم Türklerde hanım ETDR, } 1 & 1 & 2\end{array}$ 665; kadim Türkîde bazı unvanlara te'nisde "m" ilavesiyle bey hatunlarına begum ve han zevcelerine hanum denmiştir.. LO-1, 537; (خانم Bey zıddı DTO, 24; hürmetli kadın.. OTILL-2, 


$$
\begin{aligned}
& \text { خانمه } \\
& \text { خربوزه Hुarbûzah } \\
& \text { خز Hazâneçî } \\
& \text { دادا Dada } \\
& \text { داداجى Dadacî } \\
& \text { Dârûga }
\end{aligned}
$$$$
\text { داغ Dâ̆ }
$$$$
\text { Dâfi' Top }
$$$$
\text { Dulma mirç }
$$

$$
\begin{aligned}
& \text { Dيبجִ Dibçik } \\
& \text { ديجִ Dipçîk } \\
& \text { ديو Dîv }
\end{aligned}
$$

332; han ism-i turkisinin muenne-sidir.. KT, 571; TS, 843; AT-2, 251; GD-3, 180

1.Hanımefendi.2.Hanım, eş. PED
Kavun PED, 313; avokado
PEDA, 253

$\begin{array}{lll}3 & 8 & 2\end{array}$

( قاريوز Karpuz ETDR, 864; 1132

( قاريوز KT, 1020; (قاريوز LO2, 865; TS, 1092, F; GD-3, 380

Hazineci PED, 314; PEDA, 256 Hazine muhafizı, müdürü.. $\quad 2 \quad 9 \quad 2$

OTİL-2, 311

Baba veya abiye bir seslenme ifadesi. DPPL, 69, H; baba PED, 332; baba PEDA, 271

(دנه Dede, dervişlerin lakabı 1112 ETDR, 684; (دده büyükbaba, cedd-i tarik LO-1, 567; babadan dede DTO, 315; ata, ced.. OTIL-1, 205; LÇ, 168; (دده KT, 603; TS, 481; baba DLT, 246; AT-1, 506; CEAT, 451; GD-3, 190

1.Babacım. 2.Babacım (yaşlı adam). PED, 332

Müdür, ustabaşı.. DPPL, 69, F; muhafiz subay.. DTO, 315; 1992 1.Kaymakam. 2.Hapis-hane müdürü, Hapishane bekçisi. 3.Polis müfettişi PED, 333; müdür PEDA, 272

şehir hakimi OTİL-1, 235;

taraf-1 hukumetten hirmen ve zehayir muhafizı.. LÇ, 168; AT-1, 498, Mğ?; askeri vali DS-4, 1374; moğul idare teşkilâtında idârî ve malî hattâ siyasî salâhiyetlere mâlik bir kısım büyük memur-lara verilen bir isimdir ki.. MEB İA-3, 486; GD-1, 319

1.Leke, iz. 2.Dağ coğrafi terimlerde kullanılır PED, 333

Leke, iz ETDR, 680, F;

Damga izi.. LN, 403, F;

nişan, yanık.. LO-1, 562; iz, nişan DTO, 316; OTİL-2, 105, Fasrça; yanık, nişan.. LÇ, 168; dağ KT, 598; yara TaS-2, 964; Atlara ve başka hayvanlara vurulan damga. Farsiler bu sözcüğü Türklerden almıştır DLT, 246; GD-2, 439

Uçaksavar topu PED, 209

Dolma biber PEDA, 282

Dolma yapmaya uygun bir tür büyük biber ÖTS-2, 1269; دلما

Dipçik PED, 356; PEDA, 293 1.Taşınabilir bir silahın nişan 1 alınırken omuza dayanan bölümü. 2.. ÖTS-2, 1233 $\begin{array}{llll}\text { 1. Masallarda geçen, ola } & 1 & 8 & 1\end{array}$ ğanüstü büyüklükte, insanlar gibi evlenen, çoluk çocuğu olan, iyi veya kötü olabilen yaratık. ÖTS-2, 164, F

Dev. PED, 357 


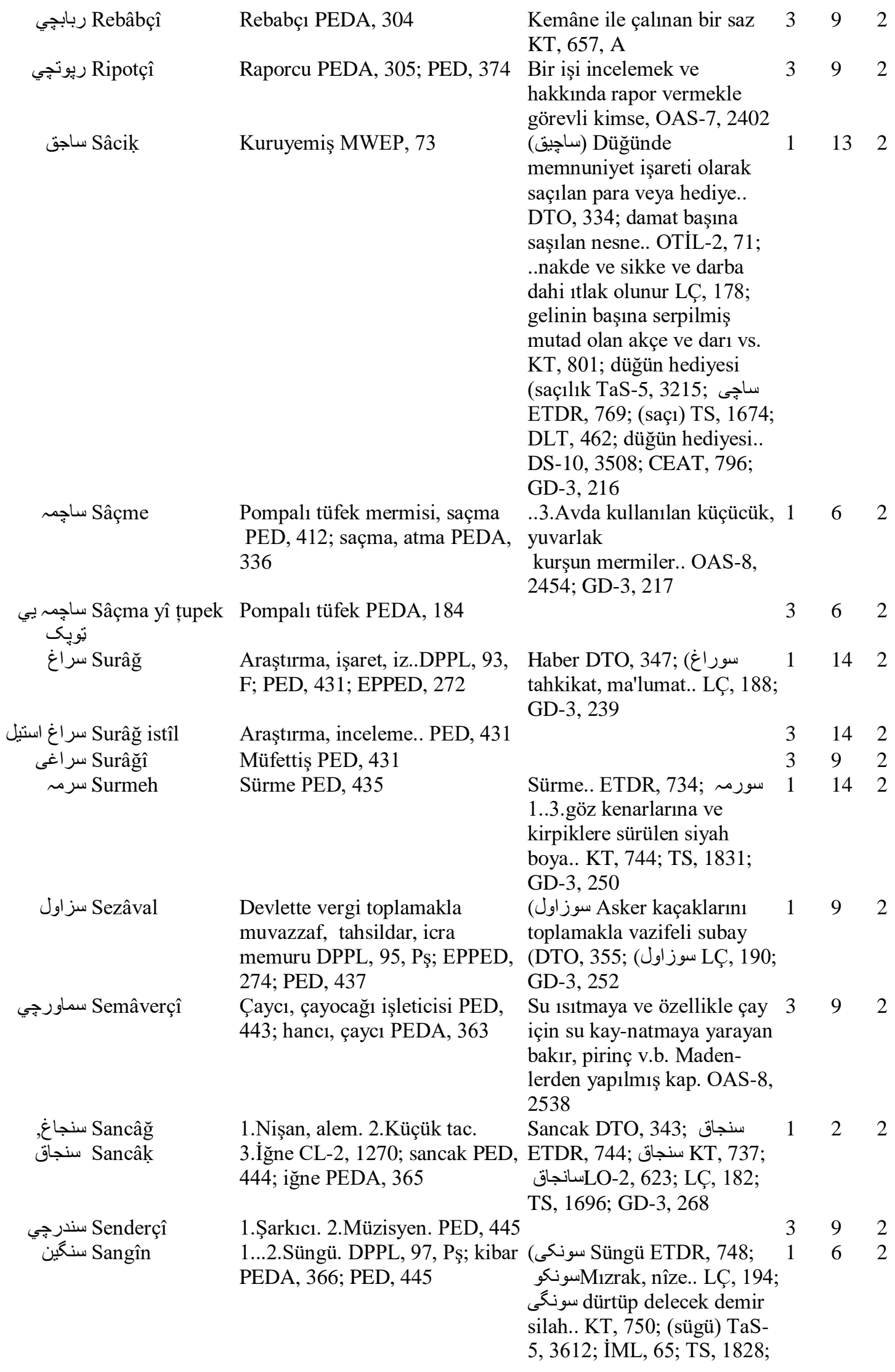




$$
\begin{aligned}
& \text { سنكين بار Sangîn bâr } \\
& \text { سنكين دل Sangîn dil } \\
& \text { سور ناجهى Surnaçî } \\
& \text { S شو شورما } \\
& \text { Arz begî } \\
& \text { Arz̧çî } \\
& \text { Arîzaçî } \\
& \text { غاليج Ğâlîçe } \\
& \text { غالى Ğâlî } \\
& \text { غالى ادول Galî edûl } \\
& \text { غالى والا Galî valâ } \\
& \text { غاوجي Ğavçî } \\
& \text { قابجى Kabçî }
\end{aligned}
$$

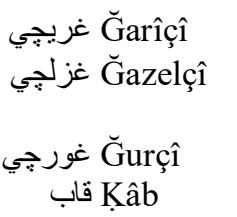$$
\text { قات Kât }
$$

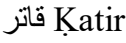$$
\text { قاترى Katirî }
$$$$
\text { قجاجق Kâçâk }
$$

قاجقى Kâçâḳ̂̂
Askerî nakliye aracı, süngü yüklü? PED,446

Süngü kalp; süngü gönüllü, acımasız, kalpsiz. PED, 446

Zurnac1. PED, 449

Çevirme, Döner

Şikâyet makamı Afganistan

Adalet Bakanlığ 1 PED, 502

Dilekçeci PED, 502

Yolluk, kilim, küçük halı.

DPPL, 114, A; PEDA, 420;

EPPED, 293, A; PED, 511

Halı dokumak. PED, 511

Halıc1. PED, 511

1.Kapıc1. 2.Bekçi PED, 511;

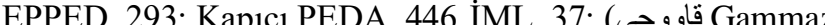

$$
\text { fettan.. LÇ, 224; TS, 1069; }
$$

CEAT, 584

1.Dağ. 2.Dağcı PED, 515

Gazelhan, şarkıcı PED, 517; PEDA, 425

(Gar) Mağara. ÖTS-2, $1641 \quad 2 \quad 9 \quad 2$

(gazelhân) Gazel okuyan; $\quad 2 \quad 9 \quad 2$

gazel söyleyen ÖTS-2, 1659

Şakacı, palyaço PED, 523

1.Kab, tabak. 2.keading. 3.Kâse Kap ETDR, 862, A; Kap,

PED, 542; PEDA, 446; EPPED, heybe DTO, 390; çanak. 299, A

LÇ, 211; zarf, gilaf.. KT, 1012; LO-2, 850; TS, 1065;

CEAT, 578; GD-3, 366

Kat, yaprak, yatak, tabaka PED, Bir yapıda iki döşeme 543; PEDA, 446 arasinda yer alan oda ve dairelerin tümü ÖTS-3,

2465; GD-3, 419

Katır PED, 543; EPPED, 300

Katır ETDR, 867; İML, 38;

LO-2, 878; LÇ, 227; asl1 قاتير

erkek eșekle kısrağın.. KT,

1030; TS, 1105; DLT, 413;

CEAT, 604; GD-3, 391;

OAS-5, 1448; AT-4, 169

Katırc1lık PED, 544

(Katırcılık) Katırcının iși, mesle-ği ÖTS-3, 2471;

(katırcilık) OAS-5, 1448

Kaçak, kaçakçılık MWEP, 188; Bulunması gereken bir PED, 543; PEDA, 446

yerden kaçan

veya gitmesi gereken bir yere gitmeyen OAS-4, 1310;

GD-3, 376; ÖTS-3, 2313;

AT-4, 35

1.Kaçakçılık. 2.Kaçakçı PED, 543; PEDA, 446

(Kaçakçıllk Devlete

$\begin{array}{lll}3 & 16 & 2 \\ 3 & 8 & 2 \\ 2 & 9 & 2 \\ 1 & 3 & 1 \\ 2 & 9 & 2 \\ 2 & 9 & 2 \\ 3 & 5 & 2\end{array}$

$\begin{array}{lll}3 & 14 & 2\end{array}$

$\begin{array}{lll}3 & 9 & 2\end{array}$

vermekle yükümlü olduğu vergi ve resmi vermemek için, OAS-4, 1310;

(Kaçakçılık ÖTS-3, 2313 


\begin{tabular}{|c|c|c|c|c|}
\hline قاز Kaz & $\begin{array}{l}\text { Kaz, kuğu MWEP, 69; PEDA, } \\
\text { 446; PED, } 543\end{array}$ & $\begin{array}{l}\text { Kaz ETDR, 866; enval çok } \\
\text { su kuşu.. LO-2, 872; IML, } \\
\text { 39; DTO, 404; KT, 1025; } \\
\text { LÇ, 219; TS, 1120; AT-4, } \\
\text { 192; GD-3, } 385\end{array}$ & 1 & 11 \\
\hline جيني قاز Çînî kạaz & Dağ kazı. PED, 543 & & 3 & 11 \\
\hline قَانش Kִaş & Eyer kaşı. PED, 543 & Eyer kassı. GD-3, 389 & 1 & 14 \\
\hline 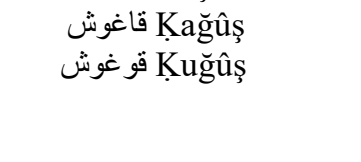 & $\begin{array}{l}\text { Hastane odası PED, 554; Yurt, } \\
\text { koğuş PEDA, } 446\end{array}$ & $\begin{array}{l}\text { Koğuş. KT, 1104; Okul, } \\
\text { kışla, hastahane, hapishane } \\
\text { gibi yerler-de, ..büyük oda. } \\
\text { OAS- } 5,1600\end{array}$ & 1 & 12 \\
\hline قافلر باشى Kâfile başî & Kervanbaşı PED, 544 & & 2 & 9 \\
\hline قاق Kâk & $\begin{array}{l}\text { 1.Kuru, kurutulmuş. 2.Sert, katı. } \\
\text { 3.çıtır. 4.Nişastalı PED, } 544\end{array}$ & $\begin{array}{l}\text { Kuru şey.. LO-2, 878; } \\
\text { kurutulmuş meyve.. DTO, } \\
\text { 406; kurutulmuş şeyler.. } \\
\text { OTİL-2, 607; güneş altında } \\
\text { kurumuş olan.. LÇ, 220; KT, } \\
\text { 1031; TaS-5, 3481, F; TS, } \\
\text { 1037; DLT, 400; kuru meyve } \\
\text { DS-6, 1893; 8, 2598; CEAT, } \\
\text { 608; GD-3, 393 }\end{array}$ & 1 & 13 \\
\hline قاقم Kâḳum & Ermin, gelincik PED, 544 & $\begin{array}{l}\text { Bir çeşit kürk.. Kaş ETDR, } \\
\text { 868; kediden küçük ve ona } \\
\text { benzer bir kürk hayvanı LN, } \\
\text { 582, F; Türk-çede as, sansar } \\
\text { ve gelinciğe mü-şabih kara } \\
\text { kuyruklu boz hayvan LO-2, } \\
\text { 879; DTO, 407; LÇ, 221; } \\
\text { aktar-1 şimaliyede bulunur } \\
\text { sansar ve gelinciğe benzer.. } \\
\text { KT, 1031; TS, } 1038\end{array}$ & 1 & 11 \\
\hline $\begin{array}{l}\text { قالين Kalîn } \\
\text { قالينج } \\
\text { Kalînçe }\end{array}$ & $\begin{array}{l}\text { Hal1, kilim MWEP, 171; DPPL, } \\
\text { 121, F; PED, 544; PEDA, 447; } \\
\text { EPPED, } 300\end{array}$ & 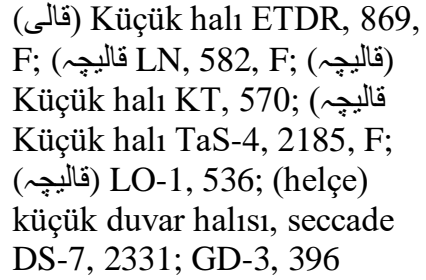 & 1 & 5 \\
\hline قالين اودون Kalîn udunkî & Halı dokuyucu. PED, 544 & & 3 & 9 \\
\hline قالين باف Kalîn bâf & Halı satıci. PED, 544 & & 3 & 9 \\
\hline قالين بافى Kalîn bâfî & Halı satıcılığı. PED, 544 & & 3 & 9 \\
\hline قايق Kâyiḳ & Kayık, sandal.PED, 544 & $\begin{array}{l}\text { Çeşitli boy ve biçimlerde, } \\
\text { kürek, yelken veya.. OAS-5, } \\
\text { 1463; KT, 1045; kayık. GD- } \\
3,408\end{array}$ & 1 & 16 \\
\hline قِّapân & Ticari tartı PED, 546 & $\begin{array}{l}\text { Büyük tartı aleti, kantar } \\
\text { ÖTS-3, 2396, A; HE, 208; } \\
\text { GD-3, 416 }\end{array}$ & 1 & 16 \\
\hline قِّapânçîn & Tartıcı, ölçücü PED, 546 & $\begin{array}{l}\text { Eskiden yiyecek } \\
\text { maddelerinin tartıldığ1 } \\
\text { kantarların başında duran } \\
\text { görevli.. ÖTS-3, } 2396\end{array}$ & 1 & 9 \\
\hline قره Kara & Kara, k1ta. PED, 543, A & & 1 & 12 \\
\hline 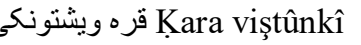 & Kitalararası füze. PED, 543 & & 3 & 6 \\
\hline
\end{tabular}




\begin{tabular}{|c|c|c|c|c|}
\hline قر قراول خانه & Karakol PED, 548 & $\begin{array}{l}\text { Karakolhane, polis karakol } \\
\text { binası ÖTS-3, 2418, Mğ }\end{array}$ & 3 & 12 \\
\hline Marâvul & $\begin{array}{l}\text { Gözcü, nöbetçi, ordunun öncü } \\
\text { muhafizı DPPL, 122; 1.Muhafiz } \\
\text { gücü, devriye. 2.Gaye. PED, } \\
\text { 548; artçı birlik PEDA, 449; } \\
\text { EPPED, } 301\end{array}$ & $\begin{array}{l}\text { Küçük bir birliğe } \\
\text { kumandanlık eden kollukçu } \\
\text { ETDR, 901; karakol LN, } \\
\text { 589, F; aslı برو gözcü, } \\
\text { dolaş1c1, asker kolu LO-2, } \\
\text { 904; قول muhafiz, gözcü, } \\
\text { karakol gücü DTO, 398; } \\
\text { gece bekçisi.. OTİL-2, 603; } \\
\text { gezici, dolaşıc1, bekçi.. LÇ, } \\
\text { 216; gözcü, nöbetçi, karakol } \\
\text { TaS-4, 2283; karakol TS, } \\
\text { 1077; 1.gece bekçisi. } \\
\text { 2.nöbetçi, gözcü DS-8, 2654; } \\
\text { AT-4, 123, Mğ; GD-1, } 399\end{array}$ & 1 & 4 \\
\hline Karâvelî & Devriye, muhafaza PED, 548 & & 3 & 4 \\
\hline ق Kirpûk & $\begin{array}{l}\text { Karakul koyununun yünü PED, } \\
548\end{array}$ & $\begin{array}{l}\text { (Kırpıt) El örgüsü ve yünden } \\
\text { yapılmış pantolon? (kırput) } \\
\text { mantı yemeği? ÖTS-3, 2631 }\end{array}$ & 1 & 11 \\
\hline $\begin{array}{l}\text { Kurut } \\
\text { Kִurût }\end{array}$ & $\begin{array}{l}\text { Bir cins çok sert peynir, } \\
\text { kurutulmuş lor tanesi DPPL, } \\
\text { 122, Pş; PED, 548; EPPED, } 301\end{array}$ & $\begin{array}{l}\text { Parça parça kurutulmuş } \\
\text { süzme yoğurt, tarhana. DS- } \\
\text { 12, 4573; HE, 270; GD-3, } \\
458\end{array}$ & 1 & 3 \\
\hline Kvret-mâçi & Kurut çorbası. PED, 600 & & 3 & 3 \\
\hline Kuretobe كورتبر & $\begin{array}{l}\text { Peyniraltı suyu kurusu. PED, } \\
600\end{array}$ & & 3 & 3 \\
\hline Kirğiz & Kırg1z PED, 548 & 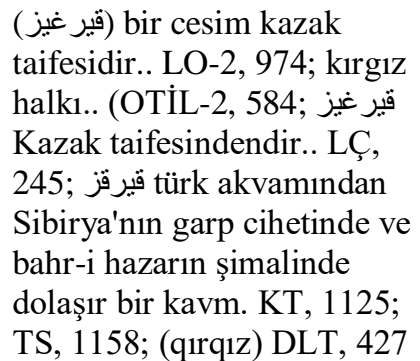 & 1 & 7 \\
\hline $\begin{array}{l}\text { كارغ Karğa, } \\
\text { قارغ Karğa }\end{array}$ & $\begin{array}{l}\text { Karga MWEP, 31; DPPL, 121; } \\
\text { PED, 543/558; PEDA, 457; } \\
\text { EPPED, } 300\end{array}$ & $\begin{array}{l}\text { Karga DTO, 30; OTİL-C2, } \\
\text { 558; karga.. LÇ, 18; İML, } \\
\text { 38; DLT, 403; ÖTS-2, 2431; } \\
\text { GD-3, 384; AT-4, } 136\end{array}$ & 1 & 11 \\
\hline كازه Kâza & $\begin{array}{l}\text {.. 2. Bir çeşit kaz. DPPL, 125; } \\
\text { PED, } 543\end{array}$ & $\begin{array}{l}\text { Kaz ETDR, 866; enva1 çok } \\
\text { su kuşu.. LO-2, 872; IML, } \\
\text { 39; DTO, 404; KT, 1025; } \\
\text { LÇ, 219; TS, } 1120\end{array}$ & 1 & 11 \\
\hline 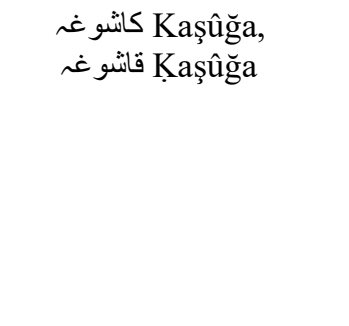 & $\begin{array}{l}\text { Kaşık MWEP, 195; Kaşık, } \\
\text { kepçe. DPPL, 121, F; Bıçak. } \\
\text { PED, 543; PEDA, 446; EPPED, } \\
300\end{array}$ & $\begin{array}{l}\text { Kaşık ETDR, 866; oyulmuş, } \\
\text { kaşınmış alet, kaşık.. LO-2, } \\
\text { 876; (قاشق) Kaş1k DTO, 406; } \\
\text { yemek yemeye yarayan alet.. } \\
\text { OTİL-2, 607; IML, 38; } \\
\text { (قاشثوق) LÇ, 220;(قاشث) KT, } \\
\text { 1028; TS, 1101; DLT, 411; } \\
\text { GD-3, 390; HE, } 216\end{array}$ & 1 & 5 \\
\hline Karabîn & Karabina PED, 557 & $\begin{array}{l}\text { Bir çeşit tüfek ÖTS-2, 2414; } \\
\text { (قر ابين) Bolca ağızlu kisa bir } \\
\text { eski tüfenk KT, 1059, Fr; }\end{array}$ & 1 & 6 \\
\hline
\end{tabular}




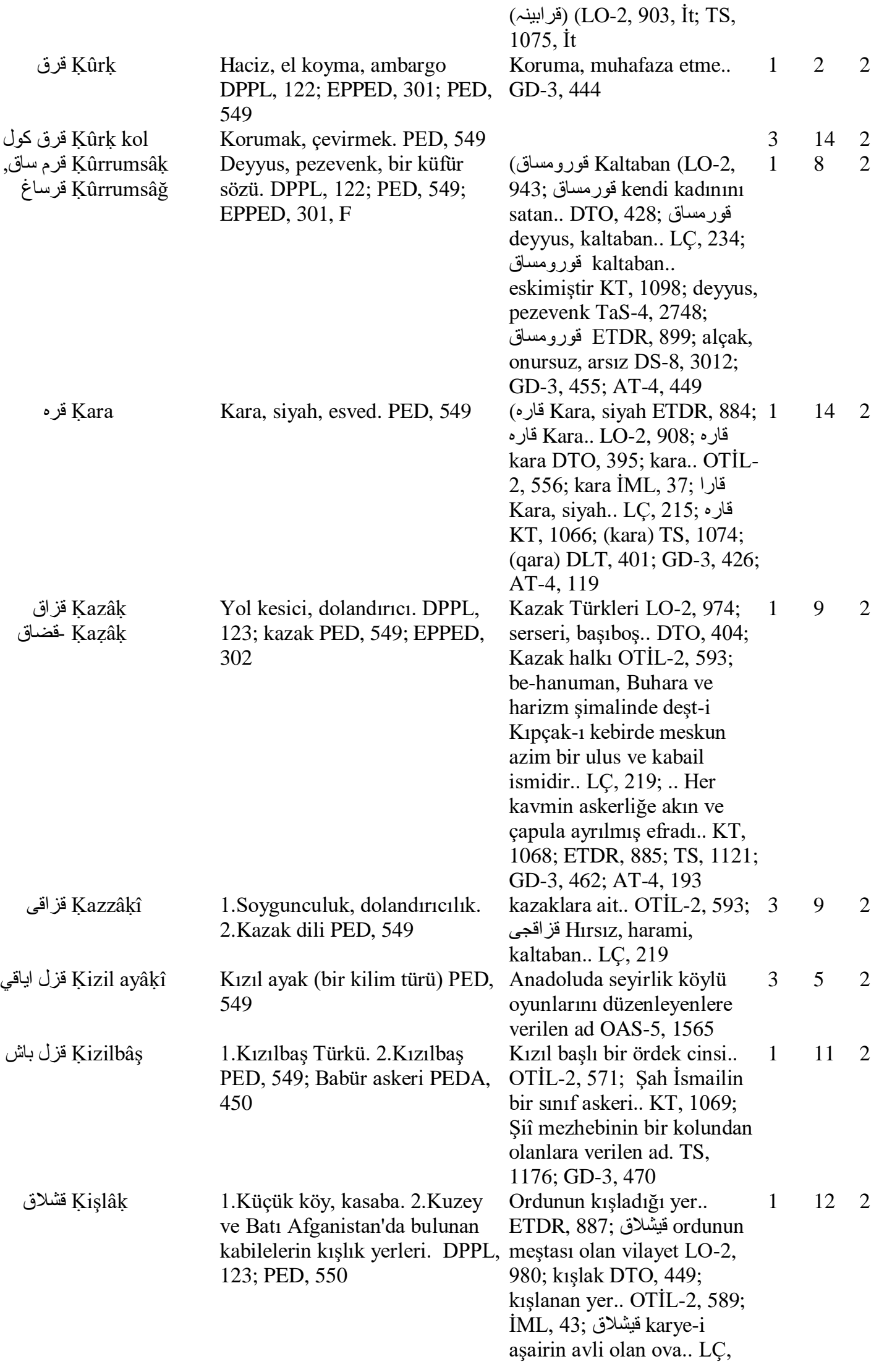




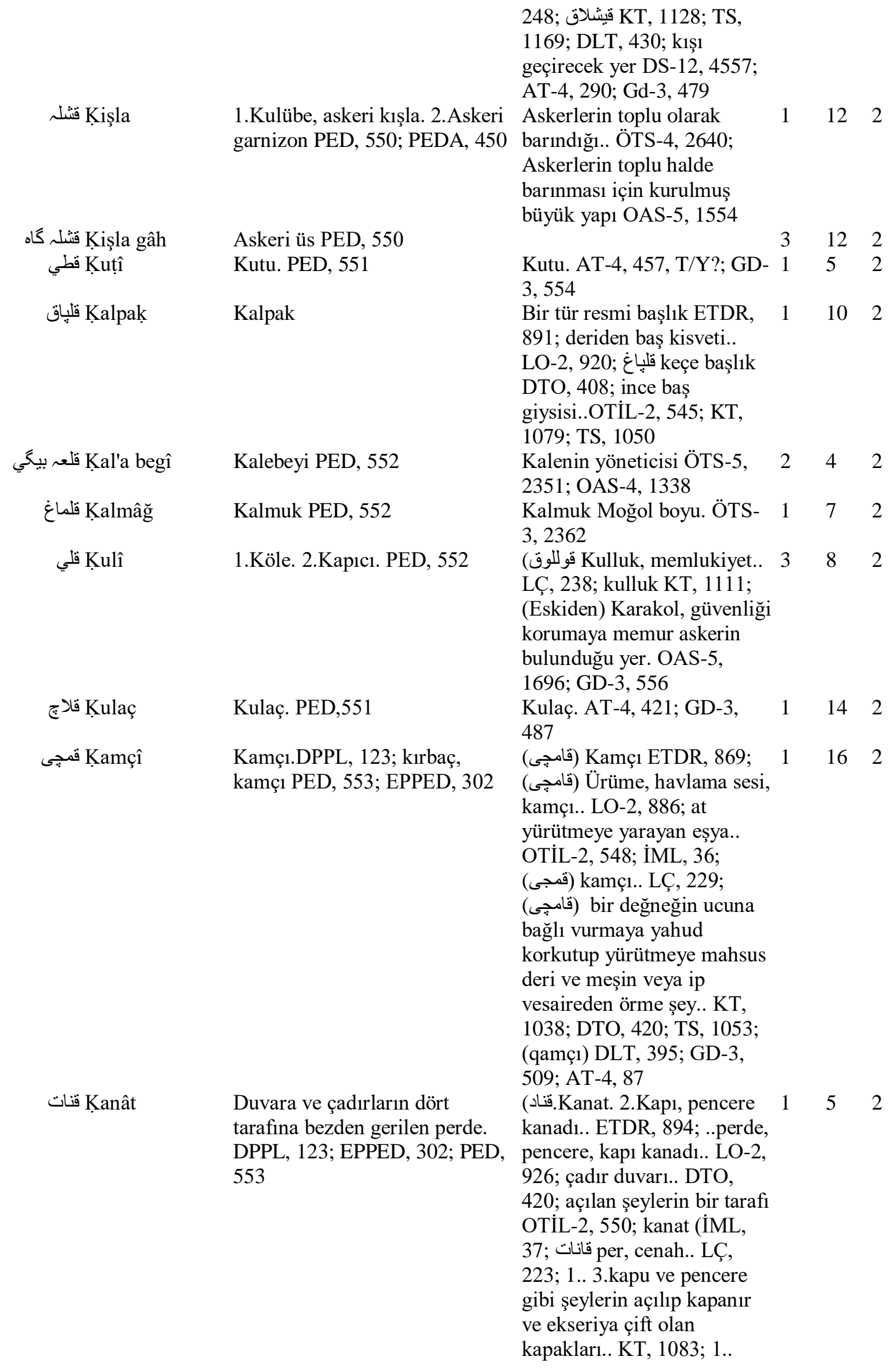




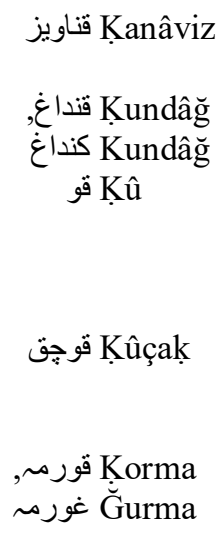

Kol

Kahveçî

قivif

قِيماغ جaymâğ çây

قيم Kiymah

Kameraçî

Sulçe
İpek kumaş PED, 553; PEDA, 453

1.Silah kundağı. 2.duba PED,

553; PEDA, 453

Kuğu PED, 553; PEDA, 453

Şişman, iri yarı, güçlü. DPPL, 124; zinde, güçlü PED, 554; EPPED, 303

Meyve ve baharatlarla pişirilmiş Et, patates, soğan vs ile bir yemek. DPPL, 124; meyve yapılan susuz bir yemek.. ve baharatla pişirilmiş kavurma et PED, 554; PEDA, 453

OTIL-2, 591; قاوورمه قاورم ; ETDR, 871; قاورمه KT, 1043; قاوورمه ; قاورومه

LÇ, 224; TS, 1112

El, hayvanın ön budu.. PED, 554 Omuzdan parmak uçlarına kadar olan uzuv.. LO-2, 956; Kul, hizmetçi.. DTO, 435; kol.. OTIL-2, 634; İML, 44; TS, 1197; DLT, 435; Kol. AT- 4,342

Kahveci PEDA, 454

1.Kahve üreticisi. 2.Kahve 292 satıcısı. ÖTS-3, 2338; OAS4, 1327

Huni, sulama kovası PED, 555; Şişe doldurmada kullanılan 1162 PEDA, 455

Sütlü çay PED, 555

alet DTO, 449

Kiyma. DPPL, 124, A; PEDA, 489; PED, 556

Kameracı PEDA, 460

Kurabiye, kek PEDA, 39-490 $\begin{array}{llll}3 & 3 & 2\end{array}$

Kıyma ETDR, 908; ekserî et 132 kıyması LO-2, 984; kıyılmış et, kıyma DTO, 452;

kıyılmış et.. OTILL-2, 574; LÇ, 249; KT, 1134; TS, 1174; GD-3, 575; CEAT, 677; PED, 575

(Kameraman) ÖTS-3, 2369; 292

(Kameraman) OAS-4, 1354

Metal çubuk veya külçe ETDR, 945; (كوليج) LN, 636, F; her türlü kümeli top şey.. LO-2, 1032; tandırda yapılan küçük ve yuvarlak ekmek OTÍL-1, 404; bir nev'î mudevver ufak nan.. LÇ, 254; yekpare dökümüş maden.. KT, 1176; TS, 1280, F; misır unundan yapılmış ekmek DS-12, 4576 


\begin{tabular}{|c|c|c|c|c|}
\hline 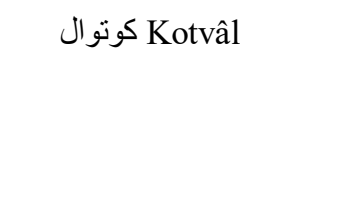 & $\begin{array}{l}\text { Köy veya kasaba karakolunun } \\
\text { memuru DPPL, } 133, \mathrm{H}\end{array}$ & $\begin{array}{l}\text { (كوناول) Muhafiz, bekçi, } \\
\text { nigehban, kal'abân.. LÇ, 257; } \\
\text { dizdar.. TaS-4, 2779, F; } \\
\text { (كوتاول DTO, 463; GD-3, } \\
618\end{array}$ & 1 & 9 \\
\hline Kotek كوتك & $\begin{array}{l}\text { 1.Kötek. 2.Çoban deyneği. PED, } \\
597\end{array}$ & $\begin{array}{l}\text { OTIL-2, 199; aşhap harp } \\
\text { aleti DTO, 217; deynekle } \\
\text { dövmek ETDR, 937; değnek } \\
\text { ve sopa ile dövme.. KT, } \\
\text { 1189; kötek 1.. 2.Sopayla } \\
\text { atılan dayak, patak TS, 1238; } \\
\text { AT-4, } 404\end{array}$ & 1 & 14 \\
\hline كو Köç & $\begin{array}{l}\text { Göç MWEP,109; DPPL, 133, F; } \\
\text { PEDA, } 485\end{array}$ & 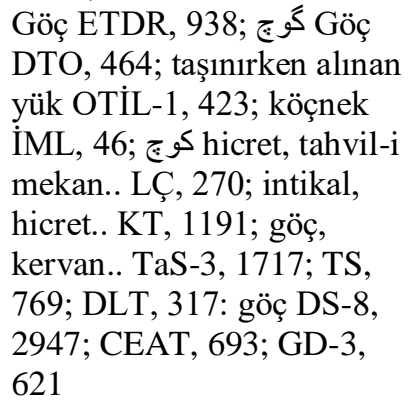 & 1 & 8 \\
\hline Kurta & $\begin{array}{l}\text { Uzun ceket. DPPL, 133, H; } \\
\text { 1.Ceket. 2.Elbise. PED, } 600\end{array}$ & Uzun üst giysisi GD-3, 587 & 1 & 10 \\
\hline Koriniş كورنش & $\begin{array}{l}\text { Birinin karşısındahürmetle } \\
\text { eğilme PED, } 601\end{array}$ & $\begin{array}{l}\text { (كورنيش Mulakat, istikbal, } \\
\text { suret-i dîdâr.. LÇ, } 271\end{array}$ & 1 & 8 \\
\hline Kolhozçî & Mandıracı PED, 605 & $\begin{array}{l}\text { S.S.C.B.'nde tarım üretim } \\
\text { koope-ratifi OAS-5, } 1607\end{array}$ & 2 & 9 \\
\hline Kuşân & Kuşan devleti. PED, 603 & Kuşanlılar devleti. & 1 & 7 \\
\hline كوكا Kukâ & $\begin{array}{l}\text { Amca (yaşl1lara hürmet ifadesi), } \\
\text { babalık? PED, } 603\end{array}$ & Koka; evlatlık. GD-1, 482 & 1 & 8 \\
\hline Kudtâçî & Devrimci PEDA, 486 & $\begin{array}{l}\text { (komitacı?) Siyasal bir } \\
\text { amaca ulaşmak için silâh } \\
\text { kullanan gizli topluluk, gizli } \\
\text { ve ihtilâlci örgüt, OAS-5, } \\
\text { 1614; ÖTS-3, } 2726\end{array}$ & 2 & 9 \\
\hline Kulâk كو لاك Ku & $\begin{array}{l}\text { Kulağası, ağa, varlıklı kimse. } \\
\text { PED, } 605\end{array}$ & $\begin{array}{l}\text { (Kullar ağası) Saray baş } \\
\text { muhafızı. GD-3, } 503\end{array}$ & 1 & 8 \\
\hline كزمه Gezme & $\begin{array}{l}\text { Devriye, gezme PED, 625; gece } \\
\text { bekçiliği, devriye gezme PEDA, } \\
502\end{array}$ & $\begin{array}{l}\text { (devriye) Dolaşarak } \\
\text { güvenliği sağlayan güvenlik } \\
\text { gücü veya görevlisi. ÖTS-2, } \\
\text { 1192; GD-4, } 4\end{array}$ & 1 & 4 \\
\hline Labratuvarçî & $\begin{array}{l}\text { Laboratuar teknisyeni PEDA, } \\
513\end{array}$ & $\begin{array}{l}\text { (Laborant) Laboratuvarda } \\
\text { yardımcı } \\
\text { olarak çalışan.. ÖTS-3, } 2921\end{array}$ & 2 & 9 \\
\hline لمبورجي Lamburçî & Kuyucu PED, 653 & & 2 & 9 \\
\hline ليلامجي Lilamçî & İhaleci PED, 664 & & 2 & 9 \\
\hline Mutalâşi & $\begin{array}{l}\text { Yıkılmaya yüz tutmuş, yıkılmak } \\
\text { üzere olan PED, } 678, A\end{array}$ & & 3 & 14 \\
\hline Muhabereçî & $\begin{array}{l}\text { Muhabereci, haberleşmeci PED, } \\
689 \text {; PEDA, } 549\end{array}$ & $\begin{array}{l}\text { Muhabere sinıfindan olan } \\
\text { asker ÖTS-3, } 3277\end{array}$ & 2 & 4 \\
\hline Merekçî & $\begin{array}{l}\text { 1.Heyet. 2.. 3.çöpçatan PED, } \\
\text { 698; temsilci PEDA, } 556\end{array}$ & & 2 & 9 \\
\hline مستعمره & Sömürgeci PED, 706 & $\begin{array}{l}\text { (müsta'mir) Sömürgeci.. } \\
\text { ÖTS-3, } 3403\end{array}$ & 2 & 9 \\
\hline
\end{tabular}




\begin{tabular}{|c|c|c|c|c|}
\hline Musharâçî & $\begin{array}{l}\text { Maskaracı, palyaço, şaklaban. } \\
\text { DPPL, 153; PED, } 707\end{array}$ & $\begin{array}{l}\text { (maskara) Gülünç, komik, } \\
\text { eğlendirici.. } \\
\text { ÖTS-3, } 3071\end{array}$ & 2 & 9 \\
\hline مشقاب Mişkâab & $\begin{array}{l}\text { Tahta tabak, hamur teknesi, } \\
\text { tabak. DPPL, 153; fincan } \\
\text { tabağ1, tabak PEDA, 563; PED, } \\
711\end{array}$ & $\begin{array}{l}\text { Tabak, tepsi vb GD- } \\
2,292\end{array}$ & 1 & 5 \\
\hline Meşveretçî & Müşavir, danışman PED, 712 & $\begin{array}{l}\text { (meşveret) İstişare. ÖTS-3, } \\
3172\end{array}$ & 2 & 9 \\
\hline Muzâhireçî & Gösterici PED, 716; PEDA, 567 & $\begin{array}{l}\text { (müzaheret) Arka çıkma, } \\
\text { koruma. ÖTS-4, } 3464\end{array}$ & 2 & 8 \\
\hline Munzam urdu & Düzenli ordu PED, 19 & (munzam) ÖTS-3, 3308 & 3 & 4 \\
\hline $\begin{array}{c}\text { مونتروان Motorvân } \\
\text { بانشيîn }\end{array}$ & Garaj müdürü PED, 741 & & 2 & 9 \\
\hline ميلر تماجا Mîle tamâçâ & Altılı tabanca PED, 203 & & 3 & 6 \\
\hline Nişançî & $\begin{array}{l}\text { Nişancı, keskin nişancı PED, } \\
771\end{array}$ & $\begin{array}{l}\text { Osmanlıda fermanları yazan } \\
\text { kimse.. ETDR, 1083; نشانجى نشانجى tuşra-keşlerin baş1 KT, } \\
\text { tuğrakeşlerin nâzırı LO-2, } \\
\text { 1176; nişanc1, atkuci LÇ, 4; } \\
\text { 884; nişan kaleminin reisi.. } \\
\text { KT, 1459; TS, } 1476\end{array}$ & 2 & 9 \\
\hline نغارجى Nağârçi & Nakkar çalan kimse. PED, 774 & $\begin{array}{l}\text { (نقاره) Davul.. LÇ, 283; davul } \\
\text { gibi eski bir nev' çalg1.. KT, } \\
\text { 1469, F; nekkare LO-2, } 1179\end{array}$ & 2 & 9 \\
\hline Naḳilçî & $\begin{array}{l}\text { Masalcı, halk hikâyecisi PED, } \\
776\end{array}$ & OTİL-1, 499 & 2 & 9 \\
\hline Nambûrçî & Lağımcı, sucu PED, 779 & & 2 & 9 \\
\hline نندارجي Nindârçî & $\begin{array}{l}\text { Seyirci PED, 780; seyirci } \\
\text { PEDA, } 609\end{array}$ & & 2 & 8 \\
\hline Nôbetçî & Nöbetçi. PED, 782 & & 2 & 4 \\
\hline دُال Dal & Kalkan PEDA, 292 & $\begin{array}{l}\text { (دال Dal, k1lıç kabzası.. } \\
\text { ETDR, 681; dal, el, kol.. LÇ, } \\
\text { 169; دال Ludağın büyüğü, } \\
\text { ağacın.. KT, 598; dal (DTO, } \\
\text { 316; dal LO-1, 563; TS, } \\
\text { 463; (tâl)DLT, } 23\end{array}$ & 1 & 6 \\
\hline 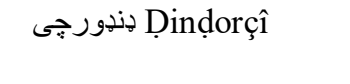 & $\begin{array}{l}\text { Münadi PED, 362; Tellal, } \\
\text { tezahüratçı PEDA, } 295\end{array}$ & & 2 & 9 \\
\hline Dolçî دولجي & Davulcu PEDA, 296; PED, 364 & $\begin{array}{l}\text { Davul çalan kişi. ÖTS-1, } \\
1116\end{array}$ & 2 & 9 \\
\hline Dulekçî & Davulcu PEDA, 297 & & 2 & 9 \\
\hline يابو Yâbû & $\begin{array}{l}\text { Küçük at, tay. DPPL, 181, H; } \\
\text { 1.Küçük at. 2.yedek at PED, } \\
\text { 845; PEDA, } 649\end{array}$ & $\begin{array}{l}\text { DTO, 464; beygir, yük atı.. } \\
\text { LÇ, 289; GD-4, } 48\end{array}$ & 1 & 11 \\
\hline پاغى Yâğ̂̀i & $\begin{array}{l}\text { Asi, düşman.. DPPL, 182, Pş; } \\
\text { PED, 846; PEDA, } 649\end{array}$ & $\begin{array}{l}\text { Düşman, hasım OAS-9, } \\
\text { 2995; HE, 438, } \\
\text { T/Mğ?;GD-4, } 99\end{array}$ & 1 & 8 \\
\hline باغيكر Yâğĝîar & $\begin{array}{l}\text { Asilik, düşmanlık DPPL, 182, } \\
\text { Pş; PED, } 846\end{array}$ & $\begin{array}{l}\text { (yağılık) Düşmanlık, } \\
\text { husumet OAS-9, } 2995\end{array}$ & 3 & 8 \\
\hline ياغيكرى Yâğ̂̂i garî & $\begin{array}{l}\text { İsyan etmek, başkaldırmak. } \\
\text { PED, } 846\end{array}$ & & 3 & 8 \\
\hline Yâğî valî & $\begin{array}{l}\text { İsyan, başkaldırı, ayaklanma. } \\
\text { PED, } 846\end{array}$ & & 3 & 8 \\
\hline
\end{tabular}




\begin{tabular}{|c|c|c|c|c|}
\hline باغى توب Yâğî tob & $\begin{array}{l}\text { İsyan, başkaldırı, ayaklanma. } \\
\text { PED, } 846\end{array}$ & & 3 & 8 \\
\hline يال Yâl & $\begin{array}{l}\text { Yele MWEP, 104; Atın yelesi. } \\
\text { DPPL, 181, F; PED, } 846\end{array}$ & $\begin{array}{l}\text { At yelesi ETDR, 1130, F; ön } \\
\text { ayağı al olan at İML, 84; ي } \\
\text { hayvanın ensesindeki sert } \\
\text { kıllar.. KT, 1554; TaS-6, } \\
\text { 4222; TS, 2160; SN, T/Mğ?; } \\
\text { GD-4, } 105\end{array}$ & 1 & 11 \\
\hline Yدedek & $\begin{array}{l}\text { Yedek at, hazırda bekletilen at. } \\
\text { PED, } 847\end{array}$ & $\begin{array}{l}\text { Yularından çekilerek } \\
\text { arkadan götürülen boş at.. } \\
\text { ÖTS-5, 5268; GD-4, } 141\end{array}$ & 1 & 11 \\
\hline $\begin{array}{l}\text { يدك بان Yedek bân } \\
\text { يدكجى Yedekçî }\end{array}$ & Yedekçi; seyis, süvari. PED, 847 & $\begin{array}{l}\text { Yedekçi, yedek atı çeken } \\
\text { kişi. GD- } 4,142\end{array}$ & 3 & 9 \\
\hline Yerâk & $\begin{array}{l}\text { Ordu, askeri teçhizat, silah. } \\
\text { DPPL, 181; donanım, techizat } \\
\text { PED, 847; EPPED, } 360\end{array}$ & $\begin{array}{l}\text { Savaş aleti, silah ETDR, } \\
\text { 1135; يار alet-i silah.. LO- } \\
\text { 2, 1216; يار alet, cihaz.. } \\
\text { DTO, 521; silah.. OTIL-2, } \\
\text { 487; yarık zirh, çokal İML, } \\
\text { 86; غرأ Muhimmat-i } \\
\text { harbiye, cephane.. LÇ, 289; } \\
\text { يار silah, alet.. KT, 1524; } \\
\text { hazırlık, levazım, techizat } \\
\text { TaS-6, 4310; TS, 2132; } \\
\text { gerekli araçlar DS-12, 4814; } \\
\text { CEAT, 962; GD-4, 143 }\end{array}$ & 1 & 6 \\
\hline Yarğâmel & $\begin{array}{l}\text { Esir, rehine. DPPL, 181, F; } \\
\text { PED, 847; PEDA, 650; EPPED, } \\
360, \mathrm{~F}\end{array}$ & Rehine, esir.. GD-4, 150 & 3 & 4 \\
\hline Yarğa & $\begin{array}{l}\text { At süsü, atların veya katırların } \\
\text { başlarında bulunan yırtmaçlı } \\
\text { süs. DPPL, 181, F; PED, } 847 \text {; } \\
\text { rahvan at PEDA, 650; EPPED, } \\
\text { 360, F }\end{array}$ & Seri koşu. GD-4, 151 & 1 & 11 \\
\hline Yasâvel يساول Ya & $\begin{array}{l}\text { Ofis yardımcısı, emir eri, rütbeli } \\
\text { bir kimsenin şahsi yardımcısı. } \\
\text { DPPL, 181, F; EPPED, 360, F }\end{array}$ & $\begin{array}{l}\text { Çavuş, rütbeli asker.. LO-1, } \\
\text { 467; teşrifat memuru, } \\
\text { muhafız DTO, 526; hanın } \\
\text { muhafızı.. OTİL-2, 488; } \\
\text { شيخا teşrifatç1, Türkis- } \\
\text { tan'da bir rütbe ismidir.. LÇ, } \\
\text { 205; muhafaza memuru, } \\
\text { yasak memu-ru.. LÇ, 293; } \\
\text { vaktiyle bölük mu- } \\
\text { hafazasına memur alay } \\
\text { çavuşu.. KT, 1548; } \\
\text { jandarma, yürütme erki } \\
\text { taşıyan görevli, karakol nö- } \\
\text { betçisi DS-11, 4192; GD-4, } \\
\text { 166 }\end{array}$ & 1 & 4 \\
\hline يغما Yağmâ & $\begin{array}{l}\text { Yağma DPPL, 181, F; PED, } \\
\text { 848; PEDA, 650; EPPED, 360, } \\
\text { F }\end{array}$ & $\begin{array}{l}\text { Yağma, talan ETDR, 1137; } \\
\text { gaspetmek, birinin malını } \\
\text { zorla elinden almak.. LN, } \\
\text { 956, F; gasp, talan.. LO-2, } \\
\text { 1234; LÇ, 59; KT, 1549, F; } \\
\text { TS, 2107, F; GD-4, 181 }\end{array}$ & 1 & 8 \\
\hline
\end{tabular}




\begin{tabular}{|c|c|c|c|c|}
\hline بورش Yûriş̧ & $\begin{array}{l}\text { Akın, istila, saldırı. DPPL, 182, } \\
\text { F; PED, } 851 \text {; EPPED, } 361, \mathrm{~F}\end{array}$ & $\begin{array}{l}\text { 1. Yürüme. 2. Hamle, } \\
\text { taarruz. ETDR, 1144; يورويش يورش hücum, akın.. } \\
\text { hücûm.. LO-2, 1261; } \\
\text { taarruz, sefer DTO, 545; LC, } \\
\text { 305; يورويش hü, } \\
\text { KT, 1560; TaS-6, 4778; GD- } \\
\text { 4, } 217\end{array}$ & 1 & 4 \\
\hline Yuḳlama & Askerî yoklama PED, 851 & $\begin{array}{l}\text { Yoklamak eylemi OAS-9, } \\
\text { 3056; 1.. 2.Aske-rin künye } \\
\text { defterine tatbiîkan tedkîk ve } \\
\text { muayenesi ve bu defterlerin } \\
\text { zabtı.. KT, } 1565\end{array}$ & 1 & 4 \\
\hline Havaî yuḳlama هو ايي يوقلم & $\begin{array}{l}\text { Hava yoklamasi; hava saldırısı. } \\
\text { PED, } \\
851\end{array}$ & & 3 & 4 \\
\hline $\begin{array}{r}\text { Da sabâ } \\
\text { دuḳlama }\end{array}$ & \multirow{2}{*}{\multicolumn{2}{|c|}{ Sabah yoklaması, ictima. PED, 851}} & 3 & 4 \\
\hline Yevkesiz & & & 1 & 12 \\
\hline 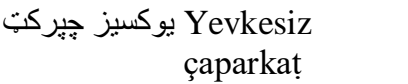 & Tek kişilik döşek. PED, 851 & & 3 & 5 \\
\hline يو لاف Yulâf & Yulaf PED, 851 & $\begin{array}{l}\text { Hayvanlara yedirilen ma'ruf.. } \\
\text { KT, } 1568 \text {; HE, } 547 \text {, ? }\end{array}$ & 1 & 14 \\
\hline Arsalân & Arslan, şahıs ismi. PED, 19 & $\begin{array}{l}\text { Aslan TS-1, 145; aslan.. LO- } \\
\text { 1, 24; aslan DTO, 12; OTİL- } \\
\text { 1, 55; IML, 11; آرسلان KT, } \\
\text { 29; R-1, 328; TS, 124; AT-1, } \\
\text { 125; HE, 20; CEAT, 238; } \\
\text { GD-2, } 39\end{array}$ & 1 & 8 \\
\hline تيمور Teymûr & Timur, şahıs adı. PED, 221 & $\begin{array}{l}\text { Demir.. TS, 493; Demir } \\
\text { ETDR, 612; LO-1, 420; } \\
\text { DTO, 267; temir, kimyevi } \\
\text { element. OTIL-2, 158; IML, } \\
\text { 27; demir, Timur.. LÇ, 137; } \\
\text { KT, 458; DLT, 550; GD-2, } \\
666\end{array}$ & 1 & 8 \\
\hline Akça & Akça, bir şehir ismi. PED, 42 & & 1 & 12 \\
\hline Balkan & Balkan yarımadası. PED, 78 & $\begin{array}{l}\text { Sarp ve ormanlık sıradağlar. } \\
\text { AT-1, } 197\end{array}$ & 1 & 12 \\
\hline Turkistan & Türkistan. PED, 185 & & 3 & 12 \\
\hline خان آباد & $\begin{array}{l}\text { Hanâbâd, bir şehir ismi. PED, } \\
305\end{array}$ & & 3 & 12 \\
\hline Urdu bazâr & Ordupazar PED, 19 & & 3 & 12 \\
\hline ياغيستان Yâğîstân & $\begin{array}{l}\text { Düşman memleketi, isyancı } \\
\text { memleketi, Afganistan'da } \\
\text { müstakil aşiretler bölgesinin } \\
\text { hususî adı. PED, } 846\end{array}$ & & 3 & 12 \\
\hline قره باغ Karabâğg & $\begin{array}{l}\text { Karabağ, Kaâbilin şimâlinde } \\
\text { semt ismi. PED, } 549\end{array}$ & & 3 & 12 \\
\hline Kizil ḳal'a & Kızılkale. PED, 549 & & 3 & 12 \\
\hline قندjunduz & $\begin{array}{l}\text { Kunduz, bir şehir ismi. PED, } \\
553\end{array}$ & Kunduz (hayvan). GD-3, 522 & 1 & 12 \\
\hline
\end{tabular}


Moğolca Kelimeler

Ağa

Ulkah

Bâverçî

Bâverçî hana
باورجي خاولن Bauli

Bahadur

Bahadurî

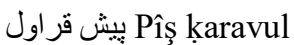

Pîs ḳaravul

Tavaçî

Cârçî
Ağalık, efendilik. PED, 38

Ağalar. PED, 41

Ağalık, nizam. PED, 41

Muharip asker PED, 58

1.Aşçı. 2.elçi PED, 79

Mutfak. PED, 79

Avcı kuş veya köpeklerin yetiştirildi-ği yer PED, 79

Bey, şehzade, sahip PED, 38; efendi PEDA, 5

Ülke PEDA, 45; الك Eyalet. 2.Öncelik. PED, 46

Civanmerd, cesur. DPPL, 17; 1.Cesaret, kahramanlık. 2. Cesur, kahraman. PED, 105; PEDA, 80

Cesaret, yiğitlik DPPL, 17; PEDA, 80

1.Özel birlik. 2.Devriye. PED, 165; artçı birlik PEDA, 114

Köy ağasnın yaveri. PED, 208

1. Haberci, tellal. 2.Ağıtçı. PED, 235; PEDA, 190
Büyük kardeş, ağabey.. TS- 1 82 1, 31; toprak sahibi, ustabaş1, en büyük erkek kardeş.. ETDR, 470; büyük, seyid, hanenin her yerin büyüğü.. LO-1, 36; abi.. DTO, 24; OTİL-1, 560; آغا Büyük efendi.. LÇ, 14; KT, 38; TaS 1, 24; UTS, 18; TS, 28; AT1, 36, Mğ; GD-1, 132

Ağalık. GD-2, 74

$\begin{array}{ll}8 & 2 \\ 8 & 2 \\ 2 & 2 \\ 4 & 2\end{array}$

(و Ordu, zirhlı birlik

DTO, 40; (اويجِين) silah, zirh.. LÇ, 23; GD-1, 111

(الكاl Ülke, vatan, toprak $\quad \begin{array}{lll}1 & 2\end{array}$

ETDRH, 484; LÇ, 39; memleket, diyar.. KT, 221;

$\mathrm{HE}, 427, \mathrm{Mg}$

Çeşnigir, bekavel.. LO-1, 11992 457; aşçı DTO, 155; LÇ, 72; (bavurçi 'aşçıbaşı AT-1, 221, Mğ

Hızlı koşan hayvan DTO, 155; terbiyeli, seriul hareket.. LÇ, 72; avcıların köpekleri alışdırmak için kullandıkları tüyden sahte kuş.. KT, 277; av tutmaya alıştırılmış.. TaS-1, 458; bavlı TS, 224; HE, 44, Mğ; AT-1, 221, Mğ

$\begin{array}{llll}\text { Savaşlarda, çarpışmalarda } & 1 & 8 & 2\end{array}$ güç ve yılmazlığıyla üstünlük kazanan veya yiğitlik gösteren kimse TS-1, 199, F; cesur, cenaver ETDR, 550, F; باتور Bahadır.. LO-1, 228; masallarda ve hikayelerde geçen dev kamet.. OTILL-1, 90; باتور LÇ, 66; batur, bahadur.. KT, 326, F; TaS-1, 456; TS, 182, F; AT-1, 187, Mğ; GD-2 , 366 Bahadurlık.. OTİL-1, 90; $1 \quad 8 \quad 2$ bahadırlık KT, 326 


\begin{tabular}{|c|c|c|c|c|}
\hline سوغات Sôgât & $\begin{array}{l}\text { Hediye, armağan MWEP, 67; } \\
\text { DPPL, 98, F; PED, 450; PEDA, } \\
370\end{array}$ & $\begin{array}{l}\text { (Savğa) Armağan DS-10, } \\
3553 ; \text { GD-1, } 345\end{array}$ & 1 & 8 \\
\hline Sôgâtî & Hediye, armağan. PED, 450 & & 3 & 8 \\
\hline سوغات كول Sôgât kol & Hediye vermek. PED, 450 & & 3 & 8 \\
\hline قابو Kâbû & $\begin{array}{l}\text { 1.Kumandan, idareci, irade, güç. } \\
\text { 2. Firsat, imkan. DPPL, 121; } \\
\text { 1.Güç, kuvvet, kabiliyet. 2.hü- } \\
\text { cuma hazır olmak. 3.tam olarak } \\
\text { PED, 543; takriben, aşağ1 yukar1 } \\
\text { PEDA, 446; EPPED, } 299\end{array}$ & $\begin{array}{l}\text { Firsat, hedef, öç.. DTO, 392; } \\
\text { GD-1, } 379\end{array}$ & 1 & 2 \\
\hline قُشون Kuşûn & Asker, ordu PED, 550 & $\begin{array}{l}\text { (قونون Asker, ordu birliği } \\
\text { DTO, 433; قوشون asker, } \\
\text { cemaat, ordu.. LÇ, 237; } \\
\text { قوشون ..birlikte sevk edilmiş } \\
\text { halk, asker KT, 1102; } \\
\text { (goşun) asker, ordu DS-6, } \\
\text { 2108; GD-1, } 406\end{array}$ & 1 & 4 \\
\hline 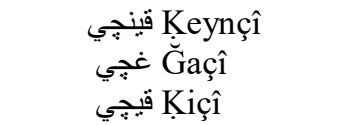 & $\begin{array}{l}\text { Makas. DPPL, 115-124; PEDA, } \\
\text { 455; PED, 555/513 }\end{array}$ & $\begin{array}{l}\text { (Gayçı/kaçı) Makas DS-6, } \\
\text { 1944-8, 2586; GD-1, } 448\end{array}$ & 1 & 16 \\
\hline فينجي كول Keynçî kol & Makaslamak.. PED, 556 & & 3 & 14 \\
\hline Keynçî jube & Keskin dil PED, 556 & & 3 & 8 \\
\hline كيشى Kişik & $\begin{array}{l}\text { 1. Nöbetçi. 2.Muhafaza, koruma } \\
\text { PED, 611; Bekçi, kapıcı PEDA, } \\
\text { 475; PED, } 581\end{array}$ & $\begin{array}{l}\text { (keşik) 1.sıra, 2.nöbet. OAS- } \\
\text { 5, 1526; sıra, nöbet.. ÖTS-3, } \\
\text { 2578, Mğ; (keşek) direk, } \\
\text { tavanı muhafaza eden direk } \\
\text { OTİL-1, 374; GD-1, } 467\end{array}$ & 1 & 4 \\
\hline كشكيجي Kişikçî & $\begin{array}{l}\text { Gözcü, bekçi, muhafiz. DPPL, } \\
\text { 129, F; Bekçi, muhafiz PED, } \\
581\end{array}$ & $\begin{array}{l}\text { (keşek) direk, tavanı } \\
\text { muhafaza eden direk (OTİL- } \\
\text { 1, 374; GD-1, } 467\end{array}$ & 1 & 4 \\
\hline Noker نوكر Nor & $\begin{array}{l}\text { Hizmetçi DPPL, 167, F; PEDA, } \\
\text { 222; EPPED, 346, F; } \\
\text { 1.Hizmetçi. 2. Asker, 3.Ulak. } \\
\text { PED, } 784\end{array}$ & $\begin{array}{l}\text { Hizmetçi DTO, 510; kul, } \\
\text { çakir.. LN, 915, F; mulazım, } \\
\text { yetim, hizmetkar.. LÇ, 283; } \\
\text { maiyet memuru, hizmetçi } \\
\text { TaS-4, 2900; ETDR, 1097, } \\
\text { F; erkek hizmetçi, uşak DS- } \\
\text { 12, 4606; HE, 301, Mğ; GD- } \\
\text { 1, 521 }\end{array}$ & 1 & 9 \\
\hline Herâvul براول & $\begin{array}{l}\text { Ordu baş muhafizı DPPL, 177; } \\
\text { PED, } 832\end{array}$ & $\begin{array}{l}\text { Karagol, gözcü.. LO-2, 904; } \\
\text { orduda gözcü asker DTO, } \\
\text { 515; ordu gözcüsü, öncü } \\
\text { kuvvet.. OTİL-2, 699; talia, } \\
\text { mukaddem piyade askeri, } \\
\text { k1lavuz.. LÇ, 287; haraval } \\
\text { yol gösteren DS-7, 2285; } \\
\text { GD-1, } 532\end{array}$ & 1 & 4 \\
\hline بلغر Yalğar & $\begin{array}{l}\text { Baskın, saldır1, akın. DPPL, 182, } \\
\text { A; EPPED, 361; PED, } 847\end{array}$ & $\begin{array}{l}\text { ( اليلغار Atın dört nala koşması, } \\
\text { düşmana açıktan saldırma.. } \\
\text { LO-1, 127; اليلغار Hafif süvari, } \\
\text { baskın.. DTO, 131; الغار Atlı } \\
\text { baskın.. ETDR, 483; ايلغار الغار } \\
\text { muharebeden evvel bir tarafa } \\
\text { sevk olunan muhafaza ve } \\
\text { ihtiyat askeri.. LÇ, 59; }\end{array}$ & 1 & 4 \\
\hline
\end{tabular}




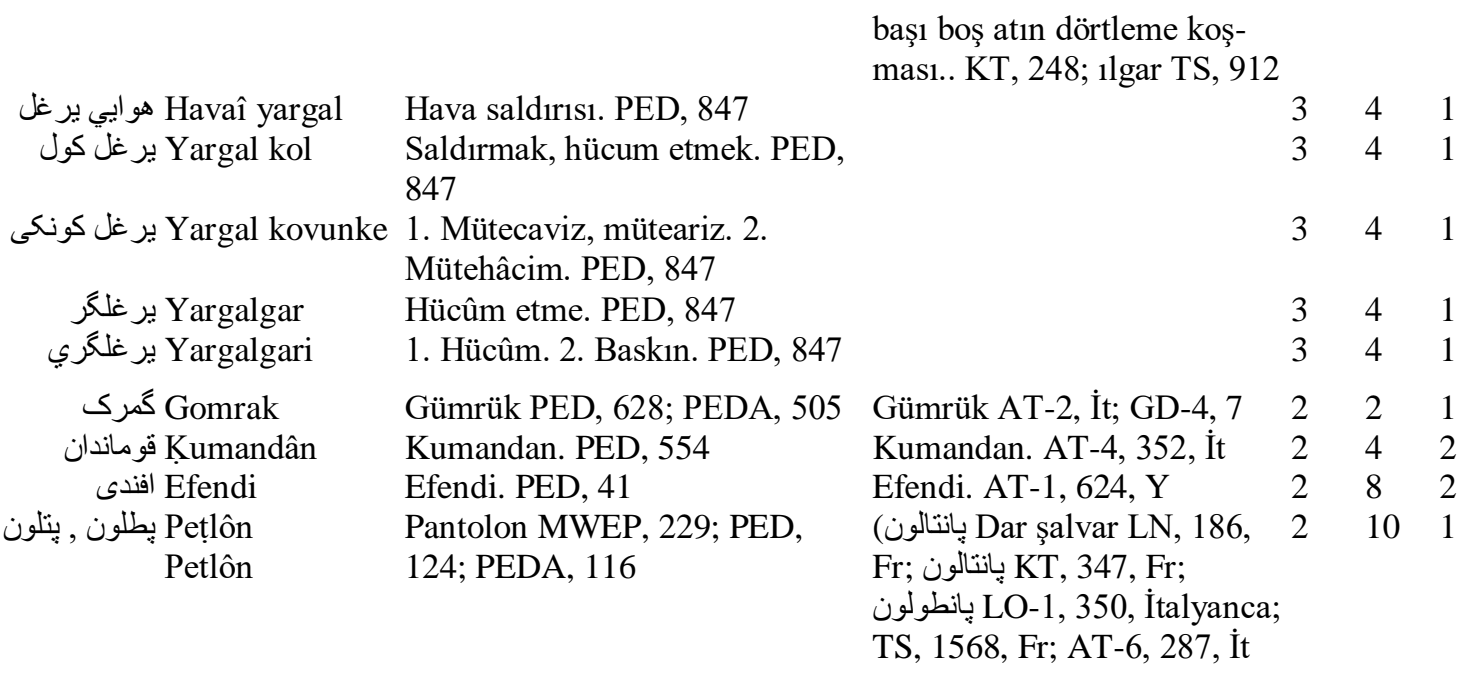

\subsection{Değerlendirme Tabloları}

\subsubsection{Tematik Gruplandırma Tablosu}

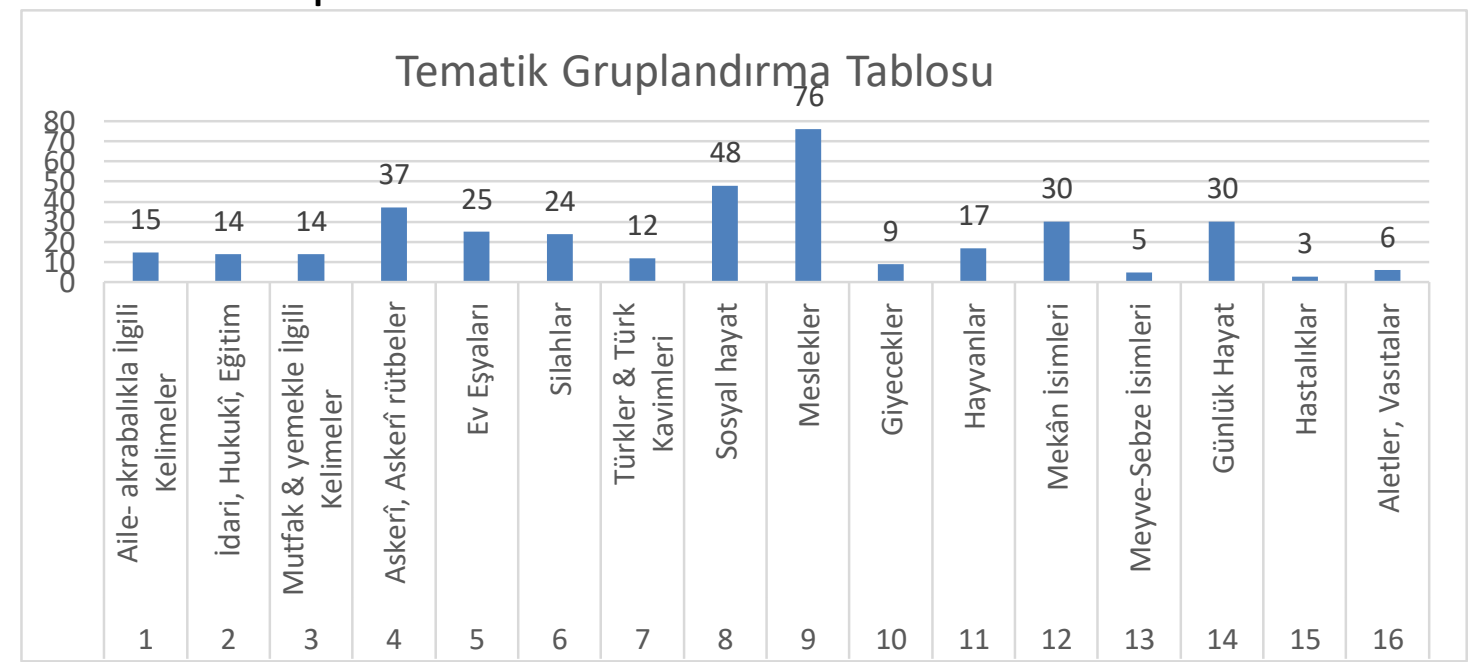

Türkçe ve Moğolcadan geçen kelimeleri tematik olarak gruplandırdığımızda meslek isimleri, askerî kelimeler ve silahlar, sosyal ve günlük hayattan kelimeler en yoğun alanlar olarak görülmektedir. Meslek isimlerinin bu kadar fazla çıkmasında özellikle Arapça, Farsça, Peştuca kelimelere -c1, -ci ekinin gelmesi etkili olmaktadır. $\mathrm{Bu}$ durum büyük oranda Türkçe/Moğolcanın Peştu dilini idarî, askerî ve ictimaî hayat bakımından etkilelediğinin göstergesidir. Yer ve mekân isimlerinden mekân isimleri çalışmaya dahil edilmiş yer isimleri ise sözlüklerde karşılaşılan dokuz yer ismiyle yetinilmiştir. Sosyal hayatın bir parçası saydığımız şahıs isimleri için özel bir tarama yapılmamış ancak yine sözlüklerde geçen iki isimle iktifa edilmiştir. 


\subsubsection{Morfolojik Değerlendirme Tablosu}

Morfolojik Değerlendirme Şeması

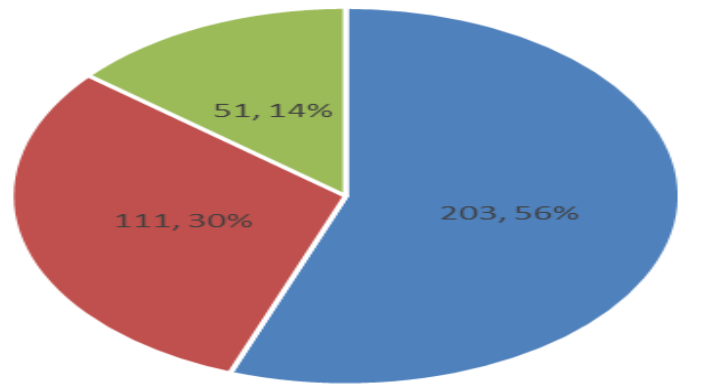

- Aslî Hâliyle Kull. Kelimeler = Hibrit Kelimeler = Ek/Unsurlarla Üretilen Kelimeler =

Peştucada ödünçlenen Türkçe ve Moğolca kelimelerin yarısı yalın hâlleriyle kullanılmaya devam etmektedir. Diğer yarısı ise Peştucada üretilen kelimelerdir. Türkçe -ci ekinin getirildiği kelimelerin ne kadarının Türkçey kelimeyle kalıp hâlinde geldiği de tartışılmaya açıktır. Çünkü bazı Farsça ve Arapça kelimelere -ci eki gelmiştir.

\section{Sonuç ve Öneriler}

Türkiye'de hak ettiği ilgiyi göemeyen dillerden birisi olan Peştuca Türk tarihi ve dili açısından oldukça önemli dillerdendendir. Ödünçlemelerin ilk merhalesi tespit ve tasnif çalışmalarıdır. Üstte tespit edilen kelime ve unsurlar başka çalışmalarda tashih ve tekmil edileceklerdir.

Peştucada ilgi çekici noktalardan birisi de komşu olduğu Urduca, Pencapça gibi dillere göre Türkçe eklerin sayıca fazlalığıdır. Moğolca kelimeler miktar itibariyle Türkçe kelimelerin onda biri mesabesindedir. Peştucaya ödünçlenen Türkçe/Moğolca kelimelerin köklerinde $\% 90$ civarında fonetik değişim yaşanmamıştır. Ödünçlemelerin saha yelpazesi -belli konularda yoğunlaşmasına rağmen- oldukça geniştir. Çalışmanın kapsamı dışında kalan noktalardan Türkçeden ödünçlenen şahıs adları, toponimiler, deyimler, tercümeler, dil kalıntıları vb. alanlarında yeni çalışmalara açık bir hâl vardır. Ortak kelimeler sözlükleri, Türkçeyle taşınan diğer dillerden kelimeler sözlükleri gibi eserler de gün yüzüne çıkmayı beklemektedir. Gelecek çalışmalara örnek olması adına (Arsalan, Teymur, Aḳça, Balkan, Turkistan, Han âbâd, Urdu bazâr, Yâğîstân, Karabâğ, Ḳizil ḳal'a, Ḳunduz, Gomrak, Kumandân, Efendi, Pețlôn) kelimeleri listeye alınmışlardır.

\section{KAYNAKLAR}

Ahmed Vefik Paşa. (t.y.). Lehçe-i Osmani. İstanbul: Cemiyet-i Tedrisiye-i Osmaniyye.

Ashraf, A. B. \& Soydan, C. (2012). Urdu-Türkçe Sözlük. İstanbul: TDK Yayınları.

Battal, A. (1934). İbn-ü Mühenna Lugati. İstanbul: TDTC Yayınları.

Bayur, Y. H. (1987). Hindistan Tarihi. 3 Cilt. (2.Bask1) Ankara: TTK Basımevi.

Bellew, H. W. (1867). Dictionary of the Pukkhto or Pukshto Language. Lahore, Pakistan: Rai Sahib M. Gulab Singh \& Sons. 
Buharî, Ş. S. E. (1880), Çağatai ve Turkî-i Osmanî. İstanbul: Mehran Matbaası.

Çağbayır, Y. (2007). Orhun Yazıtlarından Günümüze Türkiye Türkçesinin Söz Varlığı Ötüken Türkçe Sözlük I-V. İstanbul: Ötüken Yayınları.

Chand, Gh. (2007). English-Pashto Pashto-English Dictionary (Revised Updated \& expanded). New Edition. London, Engand: Simon Wallenberg.

Clauson, S. G. (1972). An Etymological Dictionary of Pre-Thirteenth-Century Turkish. London, England: Oxford University Press.

Commission, (1358h). Pakhto-Inglisi Qamoos. Kabul, Afghanistan: Afghanistan Di Uloomo Akademi. (Taranan Nüsha: Peshawar: Aryana Book Sellers, 1979.)

De Courteille, P. (1870). Dictionarie Turk Oriental. Paris, France: A L'imprimerie Imperiale.

Doerfer, W. (1965-1975). Türkische und Mongolische Elemente im Neupersischen. Bd. I-IV, Wiesbaden, Deutschland: Franz Steiner Verlag.

Eren. H. (1999). Türk Dilinin Etimolojik Sözlügü. Ankara: Şahsî Yayın.

Grierson, S.G. A. (1927). Linguistic survey of India. (Vol.1, Part. 1). Calcutta, India: Central Publication Branch.

Hanley, B. (t.y.). Mod Words English-Pashtu Dictionary. Lahore, Pakistan: Oriental Book Society.

Komisyon (1981). Uzbek Tilining Izaxli Lugati I-II. Moskva, Russija: Akademiya Nauk Uzbekskoi SSP, Moskva Izdateljtsvo Russkiy Yazik.

Karaağaç, G. (2004). Türkçenin dünya dillerine etkisi. Ankara: Akçă̆ Yayınları.

Kaşgarî, M. (2005). Divan-i Lugatit Türk. (Haz. Serap Tugba Yurteser). İstanbul: Kabalcı Yayınevi.

Komisyon. (1987). Efganistan. (4. Cilt, s. 144-146). İslam Ansiklopedisi. İstanbul: MEGSB Yayınları, Devlet Kitapları.

Sabah Gazetesi (1992). Peştu dili. S, Kılıçoğlu; N, Araz; H. Devrim. (Ed.). Meydan Larousse Büyük Lugat ve Ansiklopedi. (c. 16, s. 25). İstanbul.

TDK Yayınları (1993). Derleme Sözlüğü. 1-12. Cilt. (2.Baskı). Ankara: TDK Yayınları.

TDK Yayınları (1995). Tarama Sözlügü. 1.Cilt. (3. Bask1) Ankara:

TDK Yayınları (1996). Tarama Sözlügü. 2-8. Cilt. (2. Baskı). Ankara: TDK Yayınları.

TDK Yayınları (2005). Türkçe Sözlük. Ankara: TDK Yayınları.

Muallim Naci (t.y.). Lugat-i Naci. İstanbul.

Nişanyan, S. (t.y.). Sözlerin Soyağacı Çağdaş Türkçenin Kökenbilim Sözlügü, İnternet Portalı (nisanyansozluk.com).

Özcan, A. (1995). Eşik Ağası. Komisyon. (Ed.). TDV İslam Ansiklopedisi. (c. 11, s. 462-463). İstanbul: TDV Yayınları. 
Pashtoon, A. P. (2009). Pashto-English Dictionary. Hyattsville, USA: Dunwoody Press.

Qoraboyev, S. (2015). Peştu Edebiyatinda Kıssa Türünün Oluşumuna Genel Bir Bakış, Atatürk Üniversitesi Edebiyat Fakültesi Sosyal Bilimler Dergisi. 54, 23-28.

Redhouse, J. W. (1856). An English and Turkish Dictionary. London, England: Bernard Quaritch Oriental and Philological Publisher.

Şemseddin Sami (1317h). Kamus-i Turkî. Dersaadet İstanbul: Ikdam Matbaası.

Tuğlacı, P. (1983). Okyanus Ansiklopedik Sözlük I-X. (Altıncı Baskı). İstanbul: Cem Yayınevi.

Wardak, A. (2013). Pashto-English Dictionary. Gießen, Deutschland: VVB LAUFERSWEILER Distributors.

Yücel, D. (2013). Pakistan'daki Urduca Ve Dört Ana Mahalli Dilin Tarihleri, Kullanım Sahaları Ile Cümle Yapıları Ve Fiil Çekimlerinin Türkçeyle Mukayesesi Ve Türkçe Kelimelerinin Taranması, (Yayımlanmamış Yüksek Lisans Tezi), National University of Modern Languages, Turkish Department, İslamabad.

\section{İnternet Siteleri}

en.wikipedia.org/wiki/Pashto (07.02.2019)

www.omniglot.com/writing/pashto.htm (21.03.2019)

www.zazai.ca/wp-content/uploads/2016/12/pashto-dictionaries.pdf (22.03.2019) 